\title{
Northwest Energy Efficient Manufactured Housing Program High-Performance Test Homes
}

Tom Hewes and Brady Peeks Building America Partnership for Improved Residential Construction

September 2015 


\section{NOTICE}

This report was prepared as an account of work sponsored by an agency of the United States government. Neither the United States government nor any agency thereof, nor any of their employees, subcontractors, or affiliated partners makes any warranty, express or implied, or assumes any legal liability or responsibility for the accuracy, completeness, or usefulness of any information, apparatus, product, or process disclosed, or represents that its use would not infringe privately owned rights. Reference herein to any specific commercial product, process, or service by trade name, trademark, manufacturer, or otherwise does not necessarily constitute or imply its endorsement, recommendation, or favoring by the United States government or any agency thereof. The views and opinions of authors expressed herein do not necessarily state or reflect those of the United States government or any agency thereof.

Available electronically at SciTech Connect http:/www.osti.gov/scitech

Available for a processing fee to U.S. Department of Energy and its contractors, in paper, from:

U.S. Department of Energy

Office of Scientific and Technical Information

P.O. Box 62

Oak Ridge, TN 37831-0062

OSTI http://www.osti.gov

Phone: 865.576 .8401

Fax: 865.576.5728

Email: reports@osti.gov

Available for sale to the public, in paper, from:

U.S. Department of Commerce

National Technical Information Service

5301 Shawnee Road

Alexandria, VA 22312

NTIS http://www.ntis.gov

Phone: 800.553 .6847 or 703.605 .6000

Fax: 703.605.6900

Email: orders@ntis.gov 


\title{
Northwest Energy Efficient Manufactured Housing Program High-Performance Test Homes
}

\author{
Prepared for: \\ The National Renewable Energy Laboratory \\ On behalf of the U.S. Department of Energy's Building America Program \\ Office of Energy Efficiency and Renewable Energy \\ 15013 Denver West Parkway \\ Golden, CO 80401 \\ NREL Contract No. DE-AC36-08GO28308 \\ Prepared by: \\ Tom Hewes and Brady Peeks \\ Northwest Energy Works \\ for the \\ Building America Partnership for Improved Residential Construction \\ 37368 Blue Heron Road \\ Corvallis, OR 97330 \\ NREL Technical Monitor: Stacey Rothgeb \\ Prepared under Subcontract No. KNDJ-0-40340-05
}

September 2015 
The work presented in this report does not represent performance of any product relative to regulated minimum efficiency requirements.

The laboratory and/or field sites used for this work are not certified rating test facilities. The conditions and methods under which products were characterized for this work differ from standard rating conditions, as described.

Because the methods and conditions differ, the reported results are not comparable to rated product performance and should only be used to estimate performance under the measured conditions. 


\section{Contents}

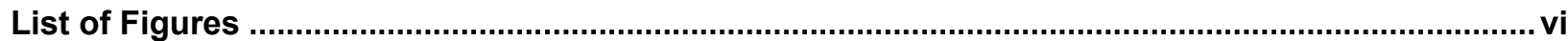

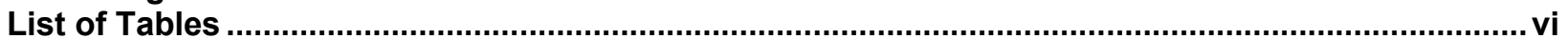

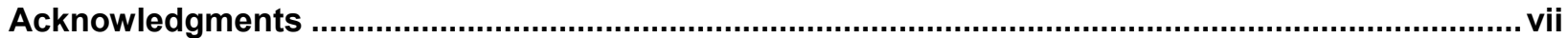

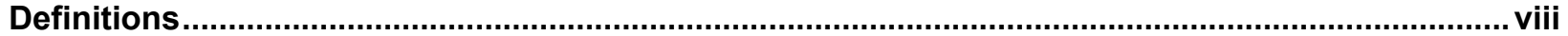

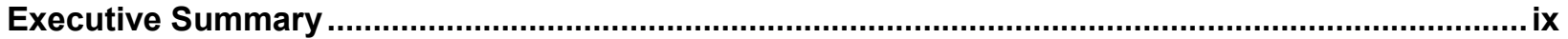

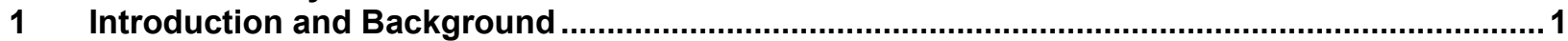

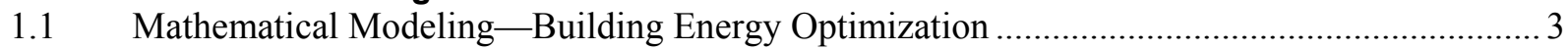

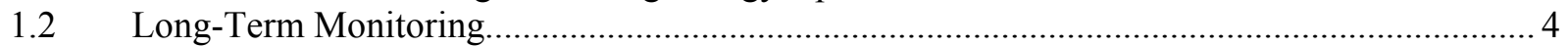

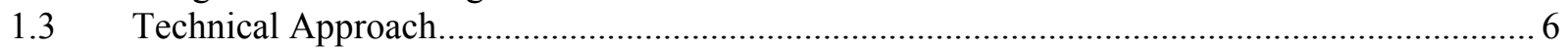

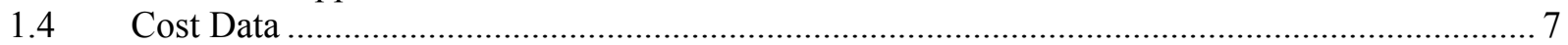

2 High-Performance Manufactured Home Construction Results ............................................ 8

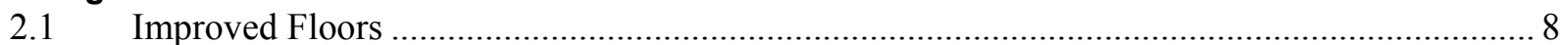

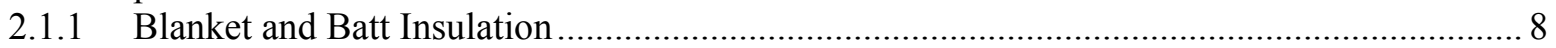

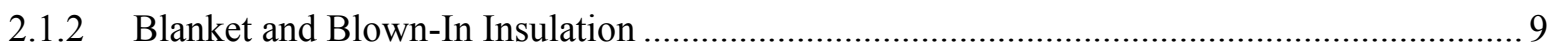

2.2 Continuous Exterior Rigid Foam Wall Insulation .......................................................... 9

2.3 Weather-Resistant Barrier and Flashing Around Windows and Doors, Details....................... 10

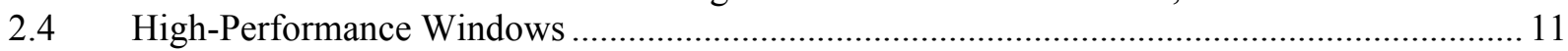

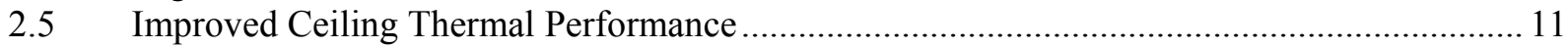

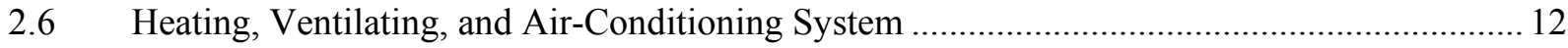

2.7 Domestic Hot Water System - Heat Pump Water Heater ...................................................... 15

2.8 Results from Building High-Performance Manufactured Home Prototypes........................... 17

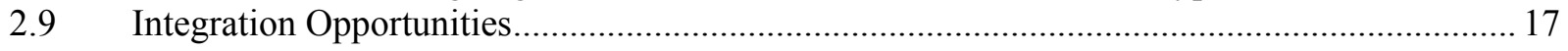

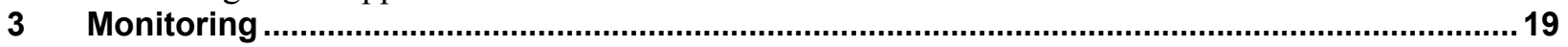

3.1 High-Performance Manufactured Home Performance ........................................................... 19

3.2 Ductless Heat Pump Performance ...................................................................................... 20

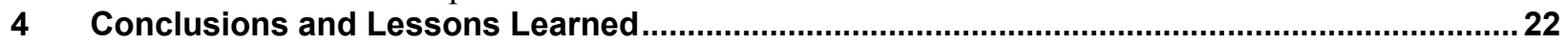

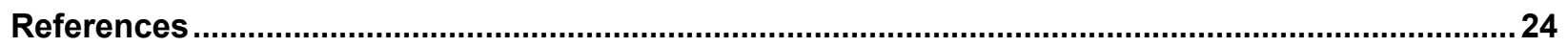

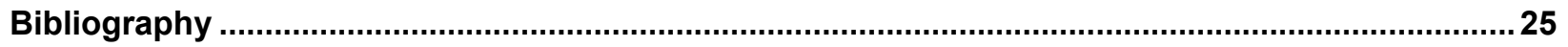

Appendix A. High-Performance Manufactured Home Quality Checklist...........................................27

Appendix B. High-Performance Manufactured Home Crawl Space Buffer Effect Validation ...........29 


\section{List of Figures}

Figure 1. BEopt V2.0 modeled annual consumption by end use 4

Figure 2. Insulation in progress, shows blankets below floor framing ........................................... 8

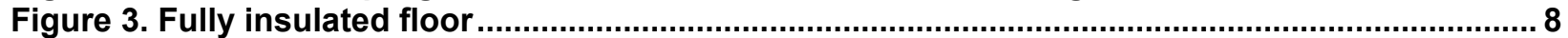

Figure 4. Blanket below framing, boxed-in utilities ................................................................... 9

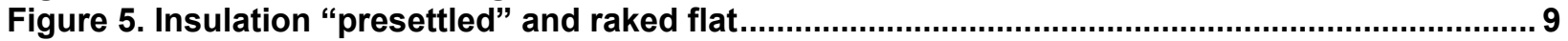

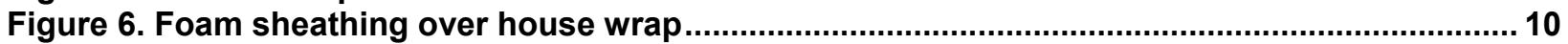

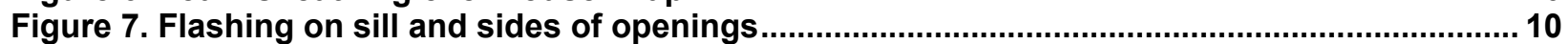

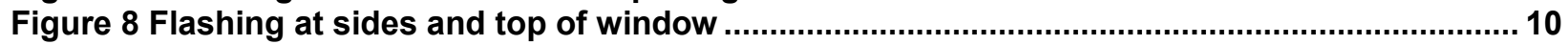

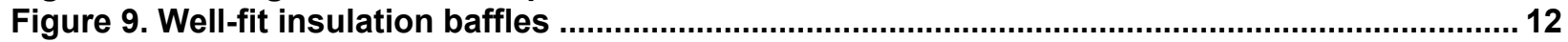

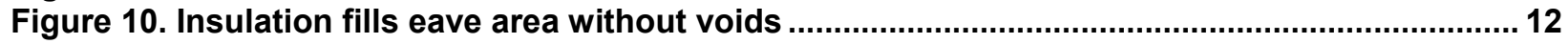

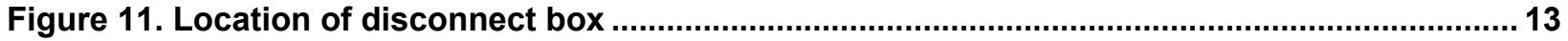

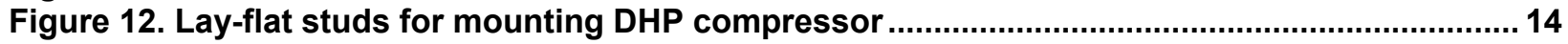

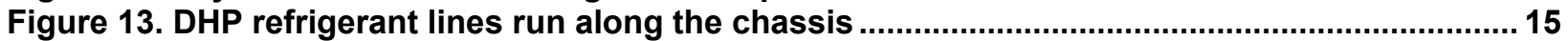

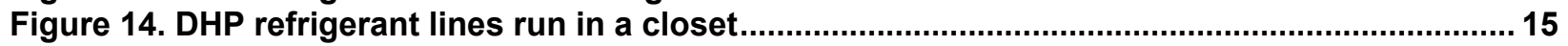

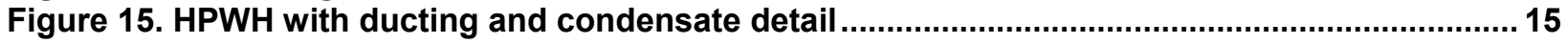

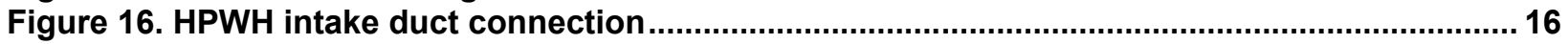

Figure 17. HPMH \#1 monthly energy use January through September 2014 (Source: SiteSage).... 19

Figure 18. HPMH \#1 crawl space buffer effect (Source: Ecotope) ..................................................... 20

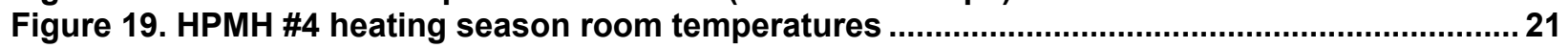

Unless otherwise noted, all figures were created by Northwest Energy Works.

\section{List of Tables}

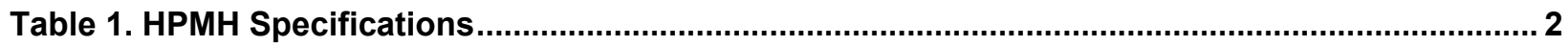

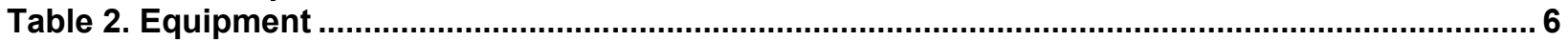

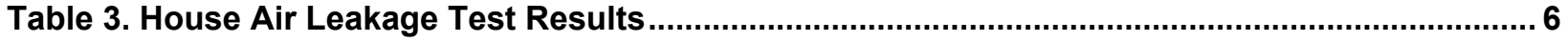

Unless otherwise noted, all tables were created by Northwest Energy Works. 


\section{Acknowledgments}

The authors thank Eric Martin and the staff of the Florida Solar Energy Center's Building America Partnership for Improved Residential Construction team who supported this project. The region's manufactured housing industry is a key group of partners in this project. Northwest Energy Works worked with many of the factories' engineering, production, and quality management personnel to design and build the high-performance manufactured home (HPMH) prototypes. The four HPMH prototypes were built at Fleetwood of Oregon, Golden West Homes, Skyline Homes, and Palm Harbor Homes. Industry partners included:

Champion Home Builders, Weiser, Idaho

Fleetwood Homes of Oregon, Woodburn, Oregon

Fleetwood Homes of Idaho, Nampa, Idaho

Golden West Homes, Albany, Oregon

Kit Homebuilders West, Caldwell, Idaho

Marlette Homes, Hermiston, Oregon

Nashua Homes of Idaho, Inc., Boise, Idaho

Palm Harbor Homes, Millersburg, Oregon

Skyline Corporation, McMinnville, Oregon

Valley Manufactured Housing, Sunnyside, Washington.

Special thanks go to Mark Johnson and Sarah Moore at Bonneville Power Administration and other regional utility partners in this project. Bonneville Power Administration actively develops the new specifications and helps bring other regional utilities to the table with the intent to develop a regional utility program to promote HPMH adoption. If and when the HPMH package begins to be included in new manufactured home construction, utility incentive funds will leverage this project's efforts by bolstering consumer demand (or lowering manufacturer costs) for higher efficiency homes.

Special thanks go to Jan and Jeff Pratt, owners of The Heat Pump Store. The Heat Pump Store specializes in ductless heat pumps (DHPs), and its staff trained the factory personnel to install DHP systems.

The Northwest Energy Efficiency Alliance (NEEA) provided support for this project by purchasing the data acquisition and monitoring equipment. NEEA also coordinated utility stakeholder discussions around HPMH efforts and opportunities for coordinated regional support of new energy efficiency enhancements to manufactured housing construction. Special thanks go to NEEA's Christopher Dymond who spearheaded the effort.

The project team also appreciates Ecotope's ongoing support with energy modeling, measure development, and data analysis. Special thanks go to Ben Larson and Jeffrey Uslan for their quick turnaround of their preliminary crawl space buffer effect analysis for its inclusion in this report. 


\section{Definitions}

$\mathrm{ACH}$

BA

BEopt ${ }^{\mathrm{TM}}$

$\mathrm{CFM}_{50}$

DAPIA

DHP

$\mathrm{ft}^{2}$

gpm

$\mathrm{HPMH}$

HPWH

HUD

HUD FMHCSS

HVAC

$\mathrm{kWh}$

$\mathrm{MH}$

NEEA

NEEM

$\mathrm{PH}$

SEEM

W
Air Changes per Hour

Building America

Building Energy Optimization Software

Cubic Feet per Minute at 50 Pascals

Design Approval Primary Inspection Agency

Ductless Heat Pump

Square Foot

Gallons per Minute

High-Performance Manufactured Home

Heat Pump Water Heater

U.S. Department of Housing and Urban Development

U.S. Department of Housing and Urban Development

Federal Manufactured Home Construction and Safety Standards

Heating, Ventilating, and Air Conditioning

Kilowatt-Hour

Manufactured Housing, Manufactured Home

Northwest Energy Efficiency Alliance

Northwest Energy Efficient Manufactured Housing Program

Person-Hours

Seasonal Energy and Enthalpy Model

Watt 


\section{Executive Summary}

This project represents the third phase of a multiyear effort to develop and bring to market a high-performance manufactured home $(\mathrm{HPMH})$. The scope of this project involved building four HPMH prototypes, resulting in an expected 30\% savings relative to the Building America (BA) Benchmark. (The actual savings amount varies depending on climate zone and the choice of heating equipment.) This work is aimed at making significant progress toward the HPMH performing as zero energy ready. Previous phases of this project created an HPMH specification and prototyped individual measures from the package to obtain engineering approvals and develop preliminary factory construction processes. This report describes the project team's work during 2014 to build prototype homes to the HPMH specifications and to monitor the homes for energy performance and durability. Monitoring is expected to continue into 2016.

The region's manufactured housing industry is a key partner. Additional partners include Bonneville Power Administration, Pacific Northwest National Laboratory, Ecotope, Northwest Energy Efficiency Alliance (NEEA), and The Heat Pump Store. The following home builders participate in the Northwest Energy Efficient Manufactured Home Program (NEEM) program:

Champion Home Builders, Weiser, Idaho

CMH West - Clayton Homes, Albany, Oregon

Fleetwood Homes of Oregon, Woodburn, Oregon

Fleetwood Homes of Idaho, Nampa, Idaho

Kit Homebuilders West, Caldwell, Idaho

Marlette Homes, Hermiston, Oregon

Palm Harbor Homes, Millersburg, Oregon

Skyline Corporation, McMinnville, Oregon

Valley Manufactured Housing, Sunnyside, Washington

Northwest Energy Works, the current program administrator for NEEM, implements ongoing construction quality management procedures and performs research with these manufacturers.

From 2011 to 2012, the U.S. Department of Energy's BA research team Building America Partnership for Improved Residential Construction, Bonneville Power Administration, and Northwest Energy Works initiated a collaborative effort to research a new set of specifications that would result in 40\%-60\% energy savings compared to typical manufactured home construction practices in the Northwest. This corresponded to a $30 \%$ savings relative to the BA Benchmark.

From 2012 to 2013, this collaborative research project's second phase defined which measures could be built into a NEEM home to achieve a 50\% reduction in the space conditioning, lighting, and water heating energy use compared to the current baseline home. The project also prototyped some of the individual measures and modeled the HPMH package, which predicted that energy savings of 8,000-11,000 $\mathrm{kWh}$ for each HPMH (or 50\% savings compared to a current practice manufactured home) could be expected from the measure package. 
During the current project phase, the team is testing and refining specifications and construction work processes to install the HPMH measure package by constructing four prototype homes, each built at a different plant. The team seeks to address questions and concerns related to the following five components.

- Ductless heat pumps (DHPs). How effectively will DHPs work with zonal heating in secondary zones? How can in-plant DHPs be reliably installed in a way that travels well to the site? Will one DHP indoor head work for all floor plans? What type or types of supplemental zonal heat will be needed? If in-plant DHP installation is not feasible, what degree of technical assistance is required to ensure quality DHP installation in the field?

- Heat pump water heaters (HPWHs). Will HPWHs work well in these homes? Will drawing air from the crawl space provide a significant benefit relative to using colder outside air? Will HPWH operation significantly change the crawl space temperature?

- New wall assemblies. What combinations of framing techniques, siding materials, fastener types and sizes, and foam thicknesses will the industry be best able to employ? How cost-optimal are the prototyped assemblies?

- Improved ceiling insulation. Do the trusses used by the manufacturing plants allow enough space to install enough insulation to meet the HPMH thermal performance targets? Can the plants successfully insulate the eave areas without leaving voids or overcompressing the insulation?

- Higher-performance windows. Can the plants readily source and receive the windows in the time frame required to fit into their construction processes? Might other thermal tradeoffs in the building envelope facilitate the use of a less expensive window and result in a lower overall package cost for the HPMH?

The project also instrumented the prototype homes to monitor long-term energy use and environmental effects. The project team worked with NEEA's Next Step Home pilot project team to ensure that the data collected are comparable to NEEA's data about similar site-built homes being monitored for its program. The team will observe the homes for durability issues.

In 2014, this project successfully built and installed monitoring devices in four HPMHs to assess energy performance. This report provides Building America, the manufactured housing industry, and regional electric utility companies with documented construction details and costs for four HPMHs, an assessment of production line impacts for new processes, and an energy monitoring plan (monitoring will continue into subsequent years). The project team also presented the HPMH to regional electric utilities and the manufactured housing industry at expert meetings.

The project team monitored the prototype homes and noted results for energy performance, durability, and process improvements in the production line.

The DHP hybrid zonal space-conditioning system appears to be performing well, providing nearly all the space heating and maintaining even temperature distributions throughout the homes.

The fully ducted HPWH was expensive, and the installation and insulation of the 6-in. intake and exhaust metal ducting was time consuming. Therefore, in the next four HPMHs, the General Electric GeoSpring 50-gallon HPWH will be used in place of the 66-gallon AirGenerate as a cost-reduction strategy. 
Exterior foam sheathing adds additional work tasks at a point in construction when most plants already experience bottlenecks, so plant workstations might need to be reconfigured. The project team plans to develop revised installation processes to test on future HPMH prototypes.

Triple-pane windows do not appear to present any significant technical challenges; however, the additional weight of the windows requires some home models to be built with an additional axle, and all the homes were delayed because of the lead time required to order the HPMH window packages.

Improving attic and floor insulation proved to be possible using commonly available materials. The project team and plant staff were able to refine and alter the original construction processes to potentially reduce the time required to achieve the desired detailing in a couple of areas, especially the attic.

This project tracked the actual cost of each HPMH prototype. The incremental "hard" costs for the energy-efficiency measures in the four HPMH prototypes averaged \$12,400 above the cost of the measures currently required to qualify homes for the ENERGY STAR energy packagewithout the markup that otherwise would be included in the factory's wholesale price to the retailer. The retail price to the consumer could be as high as \$24,000 more than an ENERGY STAR energy package, depending on how the factory and retailer set the price of the HPMH option. As of the writing of this report, two potential buyers have independently requested the HPMH package from the industry. The project's previous estimate of "hard" costs from late 2011 was $\$ 10,000$. Window costs and HPWH costs were markedly higher than the initial estimates. Optimizing the HPMH package to reduce the costs will be a focus of the next phase.

Sixteen additional person hours (PHs) were required to build each prototype HPMH. That labor direct cost is included in the overall average direct incurred costs of $\$ 12,400$ across all four plants. These extra labor PHs account for $20 \%$ of the extra costs, or approximately $\$ 2,400$. In all cases, building an HPMH was the first time plant personnel installed these measures. If this were to become a routine upgrade for the plants, the hours should decrease.

The project team built four HPMHs and modeled an HPMH package to determine the energy savings $(8,000-11,000 \mathrm{kWh}$ for each $\mathrm{HPMH}$, or $50 \%$ savings compared to a current practice manufactured home).

Preliminary energy use data from an occupied HPMH has been monitored throughout most of the 2013-2014 heating season. Monitored data compare well to SEEM and Building Energy Optimization estimates so far, suggesting that the defined HPMH measure package is likely to achieve the $50 \%$ energy savings compared to the baseline target.

The authors anticipate that the project will continue into subsequent years with ongoing field testing and monitoring of up to eight homes. This project will work with the region's electric utilities, low-income housing developers, and other stakeholders to enlist their support for a program that can result in building a significant number of energy-efficient manufactured homes. 


\section{Introduction and Background}

Northwest Energy Works has been involved with developing and administering the Northwest Energy Efficient Manufactured Home Program (NEEM) since 1987. Northwest Energy Works has signed contracts with all nine active U.S. Department of Housing and Urban Development (HUD) code builders in the Northwest. The participating NEEM builders are Marlette Homes, Kit Homebuilders West, Skyline Homes, Fleetwood Homes of Oregon and Idaho, Palm Harbor Homes, Champion Home Builders, Valley Manufactured Homes, and CMH West (Golden West Homes). The Northwest Energy Works staff has provided technical assistance to the industry as a Building America (BA) partner since 2002.

This project represents the third phase of an effort supported by the U.S. Department of Energy's Building America Partnership for Improved Residential Construction to develop a new highperformance manufactured home (HPMH) specification. This phase focuses on building and monitoring four homes built to the HPMH specification. The project team consists of Northwest Energy Works, working with the manufactured housing $(\mathrm{MH})$ industry, the relevant in-plant primary inspection agencies, design approval primary inspection agencies (DAPIAs) for the plants' retailers, industry associations, Bonneville Power Administration, Florida Solar Energy Center, the Northwest Energy Efficiency Alliance's (NEEA) NW Ductless Heat Pump Project, Pacific Northwest National Laboratory, the Northwest Power Conservation Council, Washington State University Energy Program, and regional utilities.

As discussed in two previous reports produced by the U.S. Department of Energy's BA research team Building America Partnership for Improved Residential Construction-Northwest Energy Efficient Manufactured Housing Specification Development (Hewes and Peeks 2013) and Northwest Energy Efficient Manufactured Housing Program: High-Performance Manufactured Home Prototyping and Construction Development (Hewes and Peeks 2013) — the project team has been working with the MH industry in the Pacific Northwest (Idaho, Montana, Oregon, and Washington) to develop the HPMH specification and to prototype individual measures in the HPMH package. Another focus has been to obtain approval to use the HPMH as a measure in utility energy-efficiency programs. This phase has the overall goal of helping the industry build four homes with annual potential savings of 50\% over a typical baseline $\mathrm{MH}$ produced today in the Pacific Northwest region. The potential annual savings for the HPMH are about 8,000$10,000 \mathrm{kWh}$ for each home produced and sited, depending on siting. Preliminary Building Energy Optimization software (BEopt ${ }^{\mathrm{TM}}$ ) modeling suggested that a typical home built with the HPMH package likely would meet BA Challenge Home efficiency targets. Table 1 presents a summary of the HPMH specifications.

This research to develop a viable HPMH specification is timely. New technologies such as ductless mini-split heat pumps (DHPs) and heat pump water heaters (HPWHs) are now available, but have not been adopted by MH builders. The energy-efficiency requirements in the HUD Federal Manufactured Home Construction and Safety Standards (HUD FMHCSS) are expected to be improved as the result of a review underway in 2014. At the review's completion, the federal requirements are expected to rise to a level very close to the current NEEM specifications (see Greer et al. 2004). Above-code programs such as ENERGY STAR ${ }^{\circledR}$ and NEEM will need to revise their energy-efficiency specifications once the HUD FMHCSS requirements change. 
Table 1. HPMH Specifications

\begin{tabular}{c|c|c}
\hline Component & NEEM (Base) & HPMH \\
\hline Ceiling & R-40 & R-49 nominal (R-45 net) \\
\hline Floor & R-33 & R-38 \\
Wall & R-21 & R-26 (R-21 plus R-5 foam \\
sheathing)
\end{tabular}

Notes: $\mathrm{ACH}=$ air changes per hour; $\mathrm{cfm}_{50}=$ cubic feet per minute at $50 \mathrm{~Pa}$

The available research falls short of helping MH builders to meet higher energy-efficiency standards and specifications without major production line process changes. The BA Advanced Residential Integrated Energy Solutions team is also working with the MH industry to identify high-performance building systems. The team's work to date appears to confirm that developing energy-efficiency measures much beyond what is being considered for the NEEM HPMH may involve retooling and production changes at the manufacturing plants. This HPMH project seeks to demonstrate the potential and feasibility of building a zero energy ready home without requiring significant retooling and upfront capital investment by the plants. Should the $\mathrm{MH}$ industry find market demand for the HPMH, future project phases could work with plants to weigh the costs and benefits of investing in new building technologies for long-term cost optimization of the HPMH.

Previous phase project work included designing and gaining engineering approvals for a DHP hybrid electric zonal heating system and DHP system sizing and equipment layout processes. To date, that work has helped make possible more than 90 subsequent DHP installations in NEEM homes on plants' production lines. The project team completed full in-plant installation of the DHP in three HPMHs and a DHP-ready system in one HPMH. One home manufacturer opted for field installation of the DHP because of the perceived risk of "owning" potential service issues 
for the DHP, and because of the potential for installation logistics to impact the production line. While in this instance field installation was chosen largely as a risk reduction strategy, a number of home configuration issues can make factory DHP installation impractical. Situations in which the DHP outdoor unit might need to be located on the hitch end of the home or in which the indoor head and outdoor unit might need to be mounted to different home sections occur with some regularity, especially when the DHP is being incorporated into a floor plan that wasn't drawn to accommodate the DHP.

Adding rigid foam sheathing to the walls had different impacts on the plants' production processes. The choice of siding material and framing details at studs where siding panels butt against one another can significantly impact siding fastener options. The project team investigated the maximum foam thickness that can be accommodated without significantly impacting the wall build department at a plant. This project also identified potential thermal tradeoffs that allow each plant to pursue what it considers to be its best approach to building a thermal envelope that meets HPMH targets. The project also required building wrap and adhesive-backed window and door flashing systems to prevent bulk moisture intrusion into the wall system.

Roof truss geometry varies by plant, by design roof load, and by model of home. Different plants also use different insulation materials. Previous project investigation revealed that the HPMH prototyping effort would need to develop more than one process to insulate attics to the desired level. To make the HPMH truly zero net energy, the project team conferred with the plants about the changes to typical roof trusses that may be required to accommodate the future addition of a 7- to 8-kilowatt photovoltaic array.

Each plant also has its own process for framing and insulating floors. Some plants use fiberglass blankets and batt insulation; others blow in cellulose insulation. The project team worked with the plants to ensure that each developed a process that resulted in a floor with the desired thermal properties.

Although these measures are not currently implemented in plants, the HPMH specifications represent a significant energy-efficiency measure package that can be built in plants with minimal change to the current building process. By building homes at four plants, each with its own mix of suppliers and construction methods, the project team was able to collect and verify typical costs involved with building the HPMH.

\subsection{Mathematical Modeling-Building Energy Optimization}

Modeling was performed in the specification development project phase in accordance with the December 2012 Addendum to the BA House Simulation Protocols of October 2010 (Engebrecht Metzger et al. 2014).

The HPMH specification resulted in almost 29\% savings over the BA Benchmark in a western Washington marine climate location. Figure 1 illustrates the BEopt-modeled energy consumption by end use. Typical Meteorological Year 3 sites used in analysis were Seattle, Washington; Spokane, Washington; and Kalispell, Montana. 


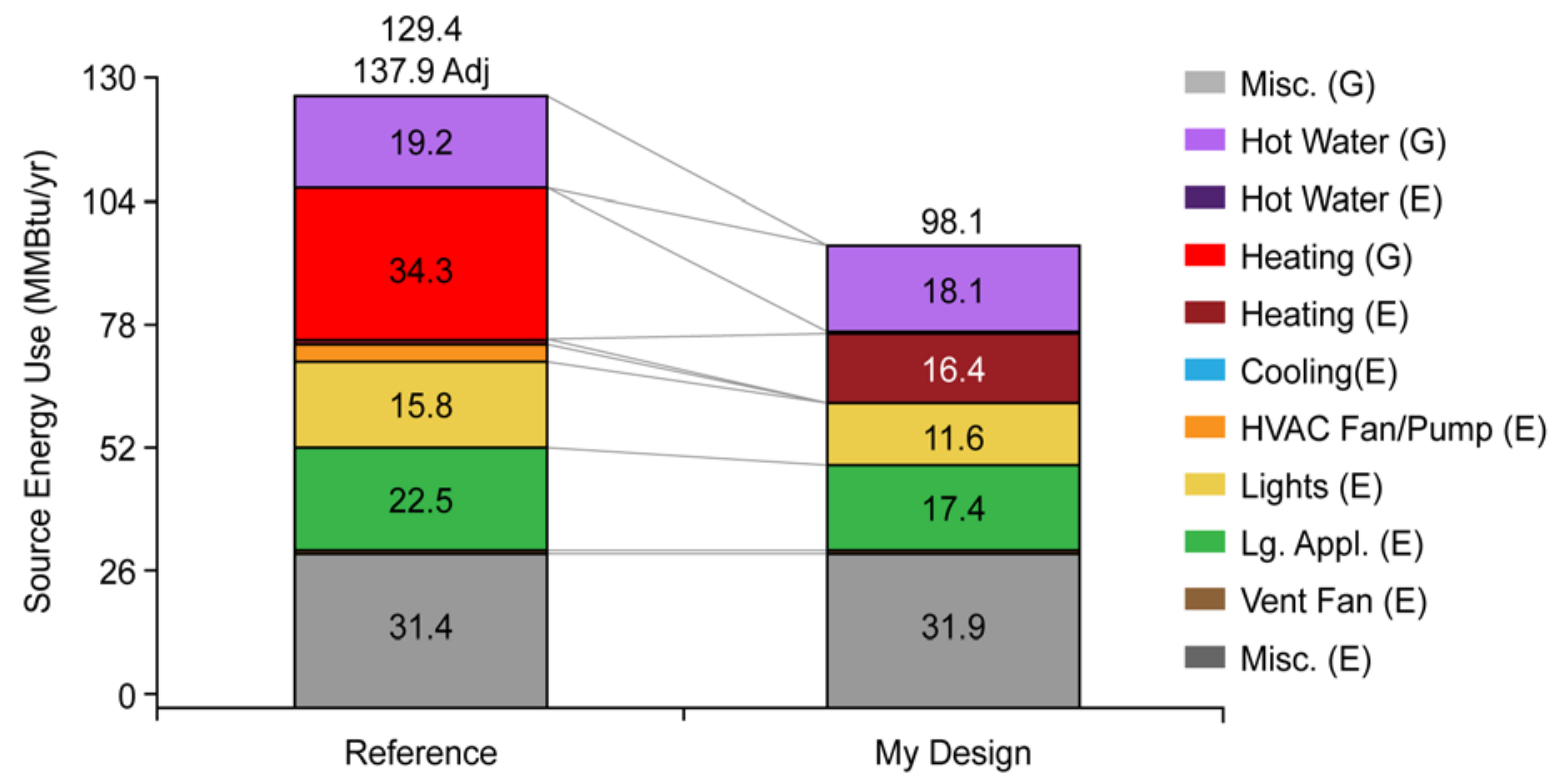

Figure 1. BEopt V2.0 modeled annual consumption by end use

The project team did not perform additional BEopt runs during this project phase because the construction of the prototype homes matched the details in the original models. The project team anticipates working with the participating factories to identify changes to the HPMH specifications and construction processes that may help make the HPMH easier or less costly to implement at the production scale. Further investigation is warranted into how BEopt treats the DHP hybrid heating system and the HPWH unit's use of air drawn from the crawl space. The BA Benchmark home assumes that natural gas is available and thus includes gas furnaces and gas water heaters. Gas is not commonly available in places where manufactured homes are sited, so most have no gas appliances. Being forced to compare the HPMH to the BA Benchmark home with gas diminishes the source energy savings for the all-electric HPMH.

Many homes being sited in MH communities in larger towns also do not have gas available because the community predates the arrival of gas to the area and the cost to install gas is prohibitive to the community owner.

\subsection{Long-Term Monitoring}

For this project, the team instrumented the four prototype homes to monitor long-term energy use and environmental effects. The project team worked with NEEA's Next Step Home pilot project team to ensure that the data collected from this project will be comparable to NEEA's data on similar site-built homes being monitored for its program. The SiteSage system from Powerhouse Dynamics is being used for the monitoring. This system consists of a powermonitoring computer connected to current transducers located in the main breaker panel. This device connects wirelessly to a gateway device that connects to the Internet and sends 1-minute interval data to the SiteSage servers, where those data become available to the project team through a dedicated Web portal. Environmental sensors, both digital 1-wire and analog, are connected to a single hub that then connects to the gateway device. This system offers the advantages of flexibility in terms of the number and types of environmental sensors deployed, 
near real-time data reporting, and multiuser capability. Sensors are collecting the following data points:

\section{Energy}

- Mains power

- DHP power

- HPWH power

- Master bedroom zone heat power

- Master bathroom zone heat power

- Additional bedroom(s) zone heat power

- Office/other purpose room(s) zone heat power

- Hall/additional bath(s) zone heat power

- Large appliance(s) power (typically clothes washer, refrigerator, and/or dishwasherdepending upon the number of open current transducer channels)

- Lighting circuits power (not exclusively lighting; the circuits usually have some outlets)

- Exterior loads included in the mains power (garage, hot tub, sewage pump, etc.).

Environmental (relative humidity and volatile organic compounds) and domestic hot water

- Living room air temperature/relative humidity/volatile organic compounds

- Master bedroom air temperature/relative humidity/volatile organic compounds

- Additional bedrooms/offices, air temperature/relative humidity

- Crawl space air temperature/relative humidity (located very close to the HPWH air intake)

- Outdoor air temperature

- Water heater inlet water temperature

- Hot water flow rate

- Water heater outlet water temperature.

Each prototype home was performance tested to determine if measures were installed in accordance with the HPMH specifications. Table 2 lists the equipment that was used to conduct the basic tests and measurements of elements of the HPMH measure package in the field.

Table 3 presents the blower door leakage readings and air change rates for the four homes. The HPMH specified target is $3.0 \mathrm{ACH}_{50}$ Pascals. HPMH \#2 had significant post-installation work performed to run Internet, cable TV, and telephone wiring to at least four locations inside the home, which disturbed the floor system. The project team did not attempt to repair the holes created by the communications contractors because such disturbances are part of what the team considered to be "typical practice." The project team did ensure that all exhaust fans had measured flows of at least $70 \%$ of rated capacity. One whole-house ventilation fan required correction by the factory technician to meet this threshold. 
Table 2. Equipment

\begin{tabular}{c|c}
\hline Measurement & Equipment Needed \\
\hline Fan Flow Rate & Flow hood or flow box \\
House Tightness & Blower door \\
\hline
\end{tabular}

Table 3. House Air Leakage Test Results

\begin{tabular}{c|c|c}
\hline Home & $\begin{array}{c}\text { Blower Door } \\
\text { CFM 50 }_{\text {PA }}\end{array}$ & $\begin{array}{c}\text { Blower Door } \\
\text { ACH }_{\mathbf{5 0}} \text { PA }\end{array}$ \\
\hline HPMH \#1 & 531 & 3.02 \\
HPMH \#2 & 640 & 3.57 \\
HPMH \#3 & 568 & 2.86 \\
HPMH \#4 & 444 & 2.75 \\
\hline
\end{tabular}

During the project's previous work to develop the HPMH specifications, Ecotope used the Seasonal Energy Enthalpy Model (SEEM) to project energy use for three different configurations of MHs using climate conditions representative of the Northwest's three predominant climate zones. The project team took the HPMH specifications and SEEM energy use projections to the Northwest Power and Conservation Council's Regional Technical Forum for peer review and acceptance of the measure package for use by utility conservation programs. The Regional Technical Forum requested follow-up research to determine whether the annual crawl space temperature profile input assumptions used in the SEEM modeling were delivering accurate estimates. The project team is answering the crawl space air temperature question with the longterm crawl space monitoring of the prototype homes.

While data collection is ongoing at the time of this writing, environmental monitoring for one HPMH has collected data from January 2014 through September 2014. Ecotope analyzed the crawl space and outdoor temperature data and compared them to its original SEEM assumptions. Although a full year's worth of data is not yet available, the modeling assumptions appear to be accurate and possibly even a little conservative. The data also show how the DHP is performing in terms of room temperature distribution throughout the home and its ability to ramp down to meet modest heating loads. Section 3.1 of this report addresses the preliminary findings in more detail.

\subsection{Technical Approach}

This project largely uses technologies that are already proven in high-performance site-built residential applications but are not yet used in the HUD code industry. The project team worked with factory engineering staff, DAPIA engineering firms, and factory production teams to build prototype HPMHs at four plants. The project team refined the preliminary HPMH construction processes developed previously as needed to account for each plant's specific construction methods. The team made sure that the resultant specifications incorporate improved efficiency measures in ways that ensure measure effectiveness and repeatability in the production environment.

The long-term energy and environmental monitoring is now supplying detailed information about the homes' energy use and occupant comfort, as well as a relative measure of ventilation effectiveness. The HPWH in the HPMH is designed to use tempered air from the home's crawl 
space to avoid comfort or depressurization issues. The exhaust air from the HPWH goes to the outside through the roof or sidewall. Monitored crawl space temperature data generated by this project have enabled the team to validate and calibrate the SEEM model's handling of this type of HPWH application.

\subsection{Cost Data}

The team compiled the actual costs incurred by each plant to build the prototype homes. Costs were then compared to the project's previous estimates to determine the HPMH's true cost to build. The project team worked with the plants' purchasing departments and material suppliers to learn which material and equipment sources were used to build the HPMHs. Any cost comparisons can result in only the most preliminary estimates of the HPMH's ultimate total cost to build and pricing in the market. The plants' parent companies use nationwide purchase contracts for many of the materials and equipment that are being changed out in the HPMH specification; thus, any "off contract" pricing for items may be significantly different than if the items were being purchased for use in plants on a regular basis.

Each factory provided cost data for building the HPMH measures. Outside heating, ventilating, and air-conditioning (HVAC) contractors were involved in installing and commissioning the DHP systems. The project team worked with the factories, home retailers, and HVAC contractors to ascertain the optimal and necessary arrangements to install DHP equipment either in the factory or in the field as part of the home setup process.

Averaged across the four plants that produced prototype homes with the HPMH package of measures, the total incurred direct costs for the measures (with no markup) came in at $\$ 12,400$ higher than the wholesale cost of the ENERGY STAR package built at that plant. This figure includes the direct labor costs associated with changes to typical production, which averaged about 16 person-hours $(\mathrm{PH})$ per home. The costs collected for the various materials used in each prototype home and for the additional labor required for each project are useful from the perspective of identifying the relative measure costs; however, this information cannot be assumed to provide significant value for determining ultimate costs and pricing for the HPMH measure package. Based upon the direct costs incurred for the HPMH measures, the retail price of the HPMH package would be $\$ 20,000$ or higher. The full sales prices of the HPMHs were not available to the project staff, but typical homes range from $\$ 75,000$ to $\$ 150,000$ depending on square footage. Site development costs and permits can add another $\$ 25,000$ to $\$ 70,000$. The team continues to work with the participating plants to ascertain the extent to which the various HPMH components might be comparably sourced at better pricing, how the production-scale construction process might be integrated into the plants, and whether other more cost-effective combinations of materials might achieve similar thermal efficiencies in the overall building envelope. 


\section{High-Performance Manufactured Home Construction Results}

All the envelope improvements and energy-efficient mechanical technologies in the HPMH package are built with readily available equipment and materials. The following energyefficiency measures were implemented in each home: improved floors, continuous exterior rigid foam wall insulation, a weather-resistant barrier and flashing around windows and doors, improved ceiling thermal performance, high-performance windows, a DHP hybrid zonal heating system, and an HPWH.

The prototype home construction activities provided an opportunity for four plants to implement the project's previously developed preliminary HPMH construction processes. The project team trained factory staff and supervised construction crews to facilitate real-time process revisions and clarify HPMH requirements. The project team now has a set of revised HPMH construction processes that capture lessons learned during each prototyping project.

The following sections describe the measures, the construction processes used by the project team and the plants to build the four homes, the challenges faced during the building process, and the outcomes from those efforts.

\subsection{Improved Floors}

The floor has no duct system. This allows up to $25 \%$ more insulation in the floor system.

Removing the ductwork also makes it practical to install floor insulation in contact with the floor deck in the area between the chassis I-beams instead of installing all the insulation below the floor framing and ductwork, as is typically done with MHs.

\subsubsection{Blanket and Batt Insulation}

Two factories insulated their floors with fiberglass blankets and batts. One layer of R-11 blanket was placed under the entire floor: rim to rim, then two additional layers of R-11 blanket were installed between chassis I-beams, also below the floor framing. Then R-21 batts were installed between $2 \times 6$ floor joists across the entire floor from rim to rim (see Figure 2 and Figure 3). Substituting high-density R-22 batts could further improve the floor's thermal performance, as would using $2 \times 8$ floor framing and thicker batts between the floor joists.

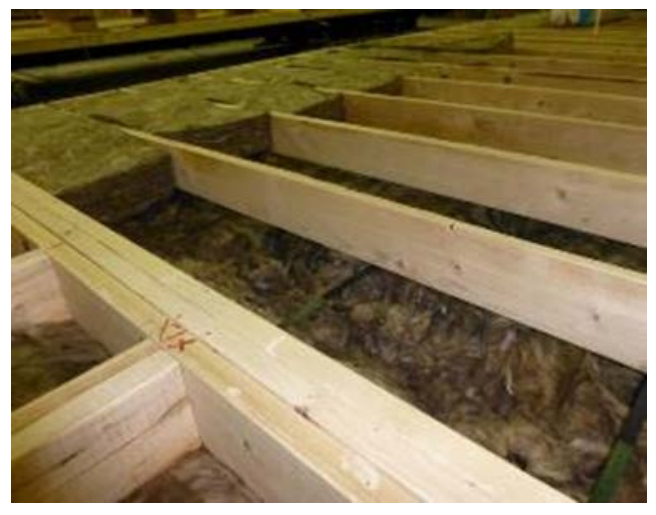

Figure 2. Insulation in progress, shows blankets below floor framing

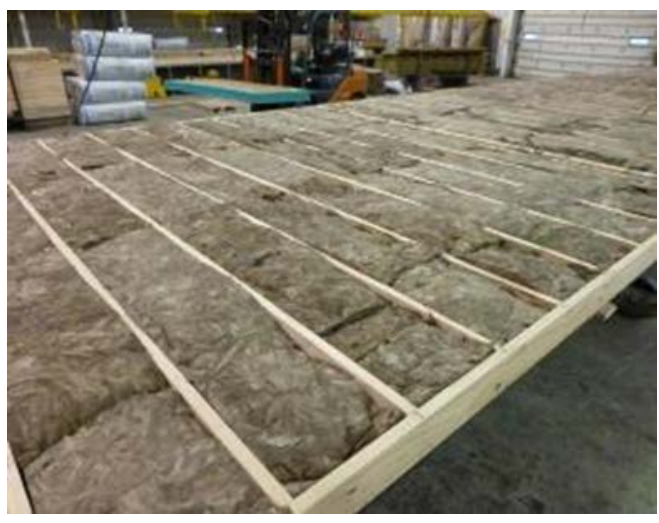

Figure 3. Fully insulated floor 


\subsubsection{Blanket and Blown-In Insulation}

Two factories used a hybrid blown cellulose/fiberglass blanket floor. One layer of R-11 fiberglass blanket was placed against the floor's road barrier fabric under the entire floor rim to rim. Stabilized cellulose insulation was blown over the R-11 blanket to fill the entire floor cavity, resulting in a maximum 13-in. installed depth of cellulose. Areas outboard of the chassis I-beams were filled to above the tops of the floor framing members and tamped until flush with the joists to prevent potential subsequent settling that could create voids between the floor decking and the rim joist. Factory staff built boxed-in areas for plumbing and wiring that were insulated with batt insulation to allow access from under the home without disturbing the blown-in insulation (see Figure 4 and Figure 5). One factory typically insulates floors exclusively with loose fill cellulose insulation, so adding the R-11 blanket between the road barrier fabric and the cellulose insulation constituted a process change. The project team requested this detail to better retain the loose fill insulation in any areas where the road barrier fabric might become damaged.

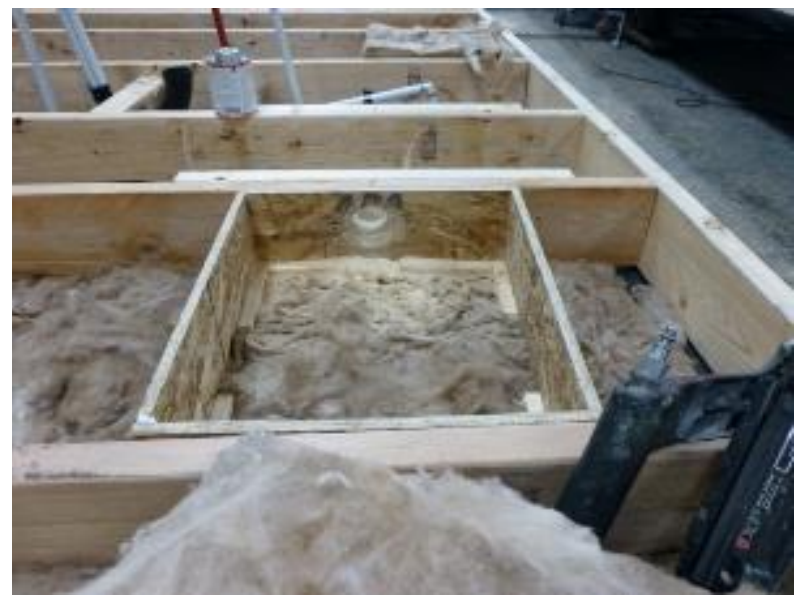

Figure 4. Blanket below framing, boxed-in utilities

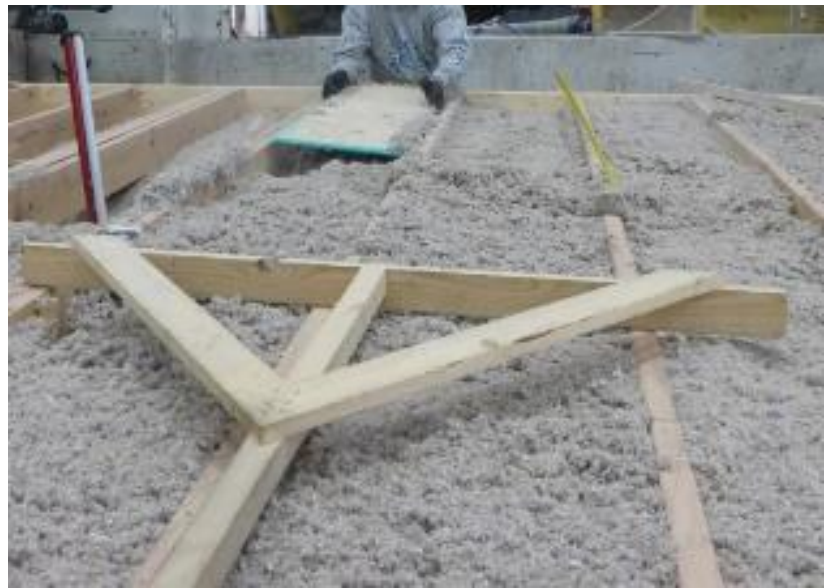

Figure 5. Insulation "presettled" and raked flat

\subsection{Continuous Exterior Rigid Foam Wall Insulation}

All four homes were built using $2 \times 6$ wall framing with R-21 insulation between studs located on 16-in. centers. A house wrap was installed against framing or structural sheathing (where applicable) with taped seams. Next, R-5 (3/4-in.) polyisocyanurate foam sheathing was installed over the house wrap, which required longer fasteners for siding installation. Extended doorjambs or lipped interior door trim, extended windowsills and/or trim were necessary to account for the increased wall thickness created by the addition of foam, but plant staff reported no significant difficulties. To accommodate a given factory's preference, other wall assemblies with similar or improved thermal characteristics could be substituted (e.g., $2 \times 8$ studs with R-30 high-density fiberglass batts, 24-in. stud spacing, or $2 \times 6$ studs with R-3 foam and high density R-22 fiberglass batts) (though none of these other wall assemblies were used in the first four HPMHs). For comparison, each factory typically builds a $2 \times 6$ wall with R-21 high-density fiberglass batts between studs located on 16-in. centers for ENERGY STAR homes. 


\subsection{Weather-Resistant Barrier and Flashing Around Windows and Doors, Details}

House wrap with taped seams was installed under the foam sheathing. All windows and doors were installed over a self-adhesive flashing. The process required factory staff to cut the house wrap at the windows and doors so that the edges could be folded into the opening. Foam and then siding were installed over the house wrap (see Figure 6). A self-adhesive flashing was installed to cover the sill and extend it up the sides of the opening by at least $1-1 / 2 \mathrm{in}$. Flashing was installed so that it extended at least 1 in. onto the face of the foam sheathing and siding. Factory staff installed peel-and-stick flashing along the sides of openings, lapping over the sill flashing and extending outward to cover the foam and siding edge (see Figure 7).

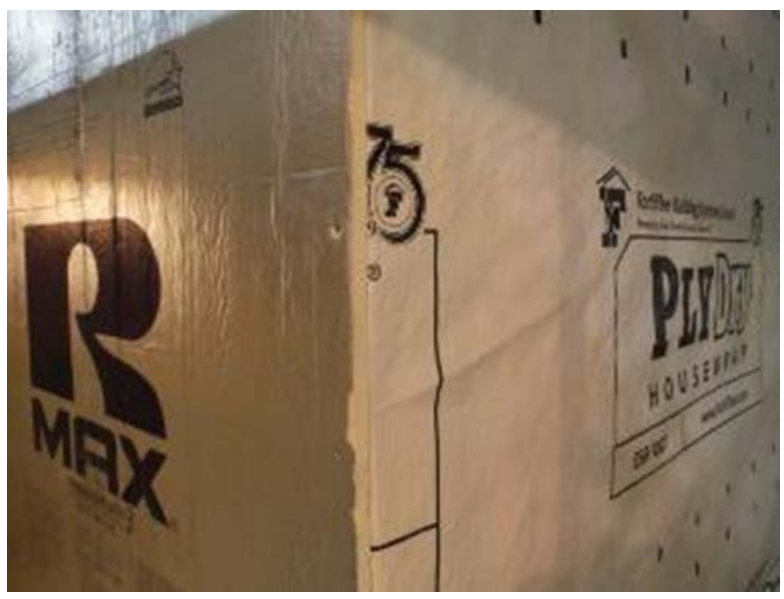

Figure 6. Foam sheathing over house wrap

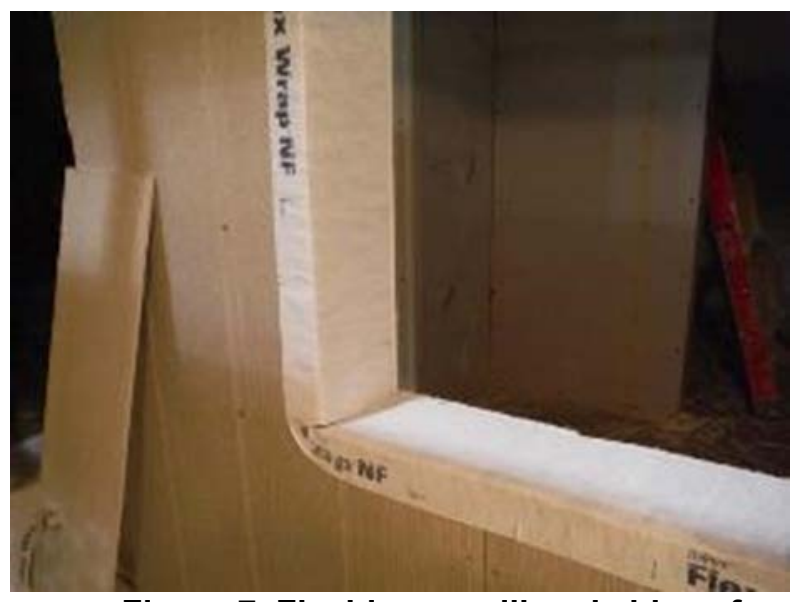

Figure 7. Flashing on sill and sides of openings

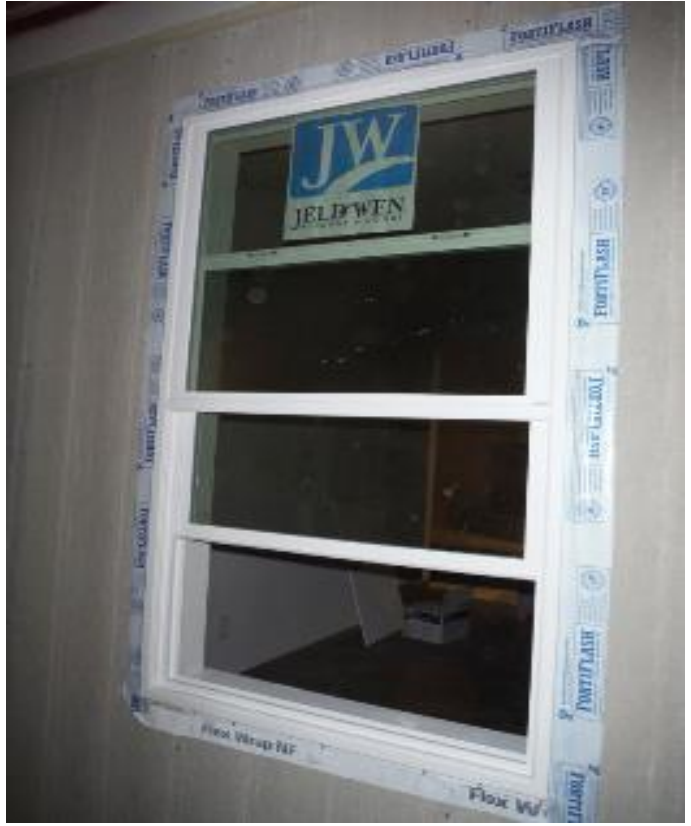

Figure 8 Flashing at sides and top of window

Windows and doors were installed using typical sealants, but longer $2-1 / 2-$ in. fasteners, rather than the 2 -in. fasteners typically used, were required in all homes to secure window nail fins to 
the wall. For windows, an additional layer of self-adhesive flashing was installed over the side nail fins. Flashing was then installed over the top nail fin and lapped over the side flashing (see Figure 8). Trim was installed in the typical fashion, using the same sealants as otherwise would be used. In some homes the flashing had to be cut down to allow the trim sufficient overlap. The doors and windows were air sealed to the rough opening from inside the home using a backer rod, caulking, or soft spray foam before installing the interior trim.

\section{$2.4 \quad$ High-Performance Windows}

Triple-pane R-5 vinyl windows are readily available in the Pacific Northwest and are commonly specified by utility-sponsored weatherization programs in the region. The company that currently supplies most of the region's MH window market does not build R-5 windows. Two window manufacturers supplying a couple of the region's MH builders produce R-5 windows, though not in product lines currently purchased by the industry. Factory staff expressed general concerns about availability and the increased cost and weight associated with triple-pane windows, fearing that the heavier units might have a greater tendency to shift and be torqued out of square during transport.

The window products used have a U-factor of 0.22 or lower and a solar heat gain coefficient of 0.28 . The windows installed were all triple-pane, low-E, argon/krypton gas filled. In all but one home the windows required an extra 2 -5 weeks' lead time from ordering to delivery. But in one $\mathrm{HPMH}$, the plant correctly ordered $\mathrm{U}=0.21$ windows from its supplier and received $U=0.24$ windows by mistake. That window manufacturer has two triple-pane window styles, one with argon/krypton gas fill and one with argon only. Filling the glazing units with heavier-than-air argon - and especially krypton gas - reduces convective currents between the panes compared to air, which lowers the U-value.

The triple-pane windows had no transport issues, except that all four homes required an additional set of axles to carry the extra weight of the glass (and other HPMH measures). Bonneville Power Administration funded the costs of the HPMH materials and equipment and was particularly interested in learning whether the factories could feasibly incorporate R-5 windows into the homes. Through discussions with window suppliers, the project team learned about the potential to bring to market dual-pane windows that have performance levels close to R-4 and a significantly lower cost than triple-glazed units.

\subsection{Improved Ceiling Thermal Performance}

All four homes required insulation baffles to fully pack insulation at the eaves. The baffles extend 36-60 in. along the rafter (depending upon the truss geometry) and include a "tail" that is at least as long as the truss heel height to allow fastening to the outside of the wall top plate (see Figure 9).

Insulation bag counts were developed that allowed for packing the eave area and achieving the R-49 target insulation depth. Insulation was packed by pushing the hose all the way under the baffle and letting the hose back itself out as it filled the area under the baffle, or insulation was blown loose in the ceiling and then manually raked down under the baffles to completely fill the cavity. The raked-away areas were then re-blown with insulation (see Figure 10). 


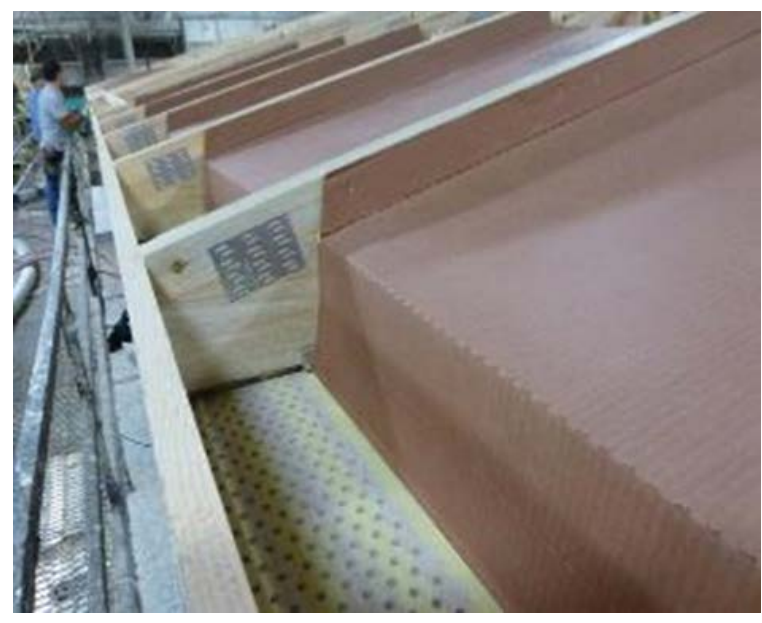

Figure 9. Well-fit insulation baffles

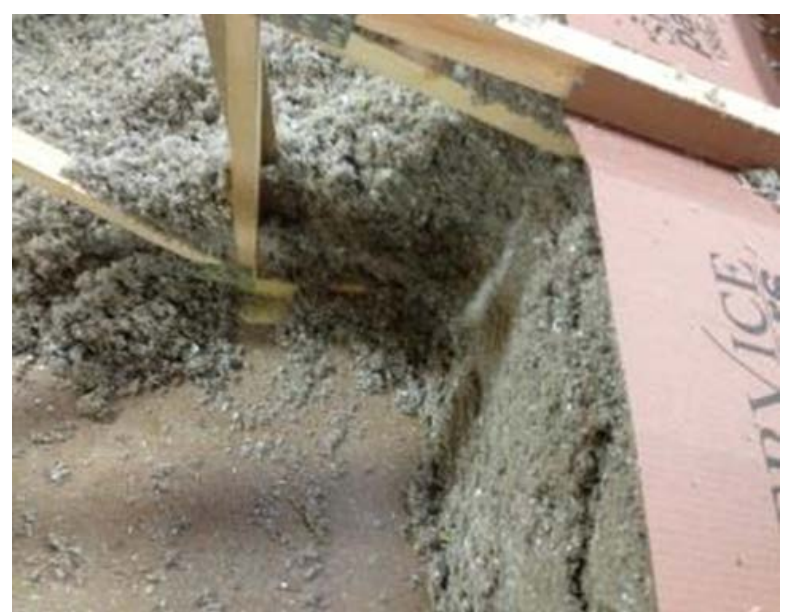

Figure 10. Insulation fills eave area without voids

\subsection{Heating, Ventilating, and Air-Conditioning System}

The hybrid zonal system eliminated the electric forced-air furnace and duct system from the home altogether, which allowed for more floor insulation where the ductwork would have been located. A single DHP was connected to one indoor head as the primary space conditioning system and was sized to meet most of the home's seasonal heating needs.

Electric wall heaters or other similar units supply secondary heating. Two approaches that plants used successfully involved either fully installing the DHP equipment in the factory or shipping the home "DHP ready" with electric resistance heating in all zones of the home and a circuit run to an exterior equipment disconnect for the DHP compressor. Project staff provided detailed training to plant staff and partner HVAC contractors in DHP hybrid zonal heating system design and installation.

Electric wall or baseboard heaters were located throughout the house so that each room has an independently controlled supplemental source of heat. The team found that a DHP could be installed and commissioned on the production line reliably and be ready for transport to the homebuyer's site. This eliminated the need for aftermarket heat pump installation. With the project team's technical support, three of the four plants were able to design for and install the DHP heating systems in the factory. For the fourth HPMH, a DHP-ready approach was required and the factory determined the size of the DHP and the locations for the interior head and outdoor compressor. In all cases the factories installed the zonal electric resistance heaters and ran a dedicated electrical circuit to a disconnect box located near the DHP's outdoor compressor.

\subsubsection{Ductless Heat Pump Hybrid Zonal Heating System Design Considerations} Single-headed DHP systems were installed in the four HPMHs. The hybrid DHP systems were designed with sufficient heating capacity, when combined with the secondary zonal heaters, to meet the load at the heating design temperature for the home site. Individual wall heater sizing was determined by a room-by-room heat loss calculation. Project staff assisted the factory with performing all heat loss and sizing calculations.

Each bedroom, office, or other habitable room that can be closed off from the main zone of the house by a door requires its own unit heater. Even if the DHP is installed in the plant the main zone of the home may require a secondary heater because the DHP may not be adequate to fully meet the main zone's load at the heating design temperature for the home site. Installing a 
resistance heater in a home's main zone can simplify the DHP design and installation process. Placing an extra zonal heater in the main zone can allow the home to ship from the plant with a complete heating system in cases where the DHP must be installed onsite.

Recessed wall heaters usually require $2 \times 4$ wall framing to fully recess the heater. The project team found $1,000-\mathrm{W}$ heaters to be a versatile size that works well for many rooms.

Fan/light/heater combo units were installed as an effective solution for providing heat in bathrooms. Bathroom units were installed and wired to allow independent operation of each function. Some bath heaters used a heat lamp, so in those cases separate low-wattage lighting was included in the bathroom for illumination purposes.

Heaters require a thermostat. Some have one integrated into the unit, others require a line voltage thermostat mounted on the wall — one thermostat per heater. Bathroom heaters may instead be controlled by a switch or timer.

Factory staff installed ceiling fans in the living room and master bedroom to maximize air mixing. For homes sited in areas with high cooling loads or homes with added glazing in bedrooms, factory staff installed paddle fans in each bedroom. The project team recommends installing paddle fans in the living room and master bedroom and making the other bedrooms paddle fan ready as part of any DHP hybrid zonal space conditioning system.

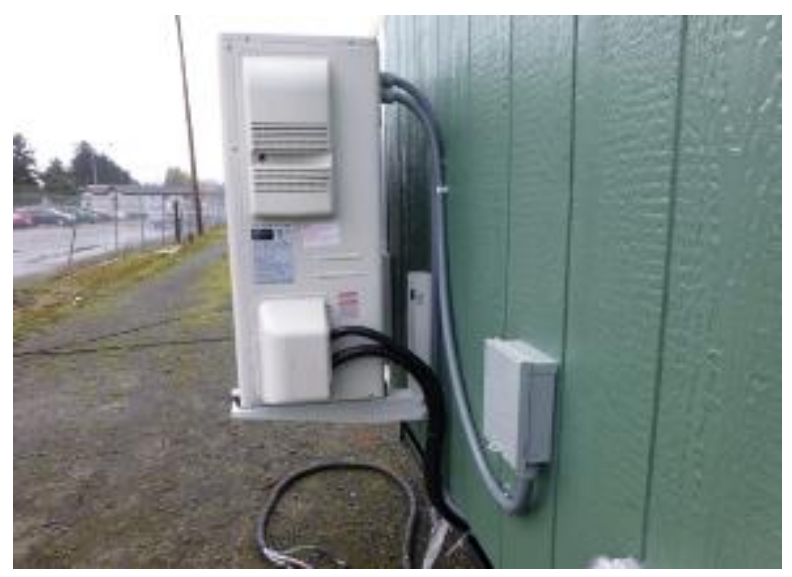

Figure 11. Location of disconnect box

Factory staff installed a $240-\mathrm{V}$ circuit with $12-2-\mathrm{G}$ wire running from either a 15 - or 20 -amp breaker in a panel (depending upon DHP selected) to the equipment disconnect box on the exterior of the home near where the DHP outdoor unit was to be located, which was $2-4 \mathrm{ft}$ to the right of the edge of the outdoor unit (see Figure 11). According to a DHP contractor who worked with the project team, connecting the DHP with 12-gauge wire is important for proper DHP functioning. Factory staff simplified the process by installing a 20 -amp breaker in the main panel and using a fused-type equipment disconnect that can be fitted with 15 - or 20-amp fuses as a cost-effective way to eliminate errors and ensure that all types of DHP units can be accommodated.

\subsubsection{Additional Items for Complete Factory Ductless Heat Pump Installation}

In a factory installation, the DHP compressor was mounted on a bracket on the nonhitch end wall of the home, on a porch, or equivalent. Project staff helped the plant size the DHP for the appropriate climate zone and provided training for plant staff and partner HVAC contractors on equipment installation details particular to this application. 


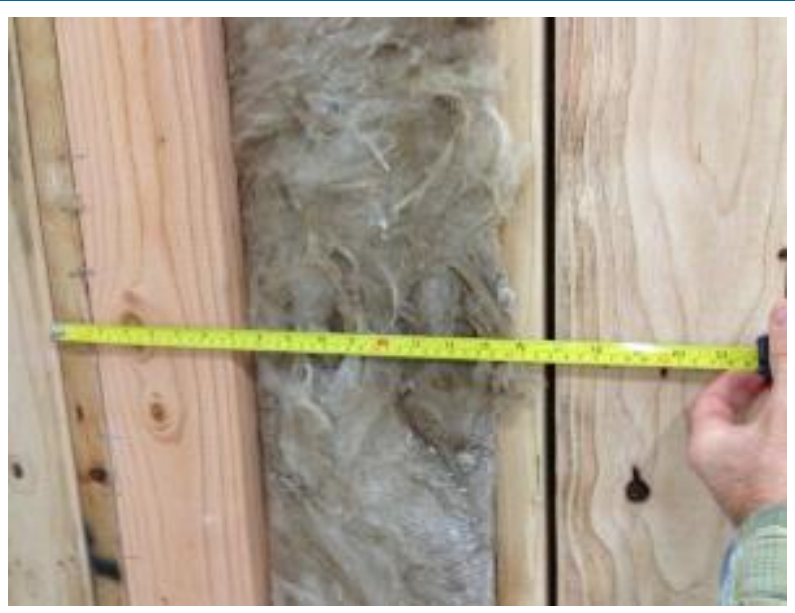

Figure 12. Lay-flat studs for mounting DHP compressor

In three of the four homes lay-flat studs were installed for mounting the outdoor unit. Factory staff determined the distance between the feet on the compressor and installed blocking or layflat studs to attach the mounting brackets (see Figure 12). Brackets that bolt directly into the wall are preferable to rail-hung systems because they provide a much more rigid attachment that is better suited to transport. Quality vibration isolators between the outdoor unit and the brackets are essential.

Factory staff used stainless steel lag bolts to connect the brackets to the wall, drilled pilot holes, and shot the holes with high-durability caulking before the lag bolts were driven into framing. The bolt heads, the washers, and the tops of the brackets received additional caulking to prevent water intrusion.

Refrigerant lines from the outdoor compressor to the indoor head can pass under the home strapped to the I-beam. In some installations setup crews need to notch the skirting or block out the continuous concrete stem wall for refrigerant lines. This requires that the setup instructions specify the dimensions and location of notching (see Figure 13).

Project staff recommends that the indoor head back up to a closet and the refrigerant line be run in the closet in a line set cover and through the floor. These measures allow full access to the refrigerant lines for future service access. Figure 14 shows the line set in place; the completed installation is shown in the inset. If the indoor head is mounted against the exterior wall with the outdoor compressor mounted on the other side, the lines are run up the outside of the wall in a line set cover and through the wall, directly to the indoor head (not shown). 


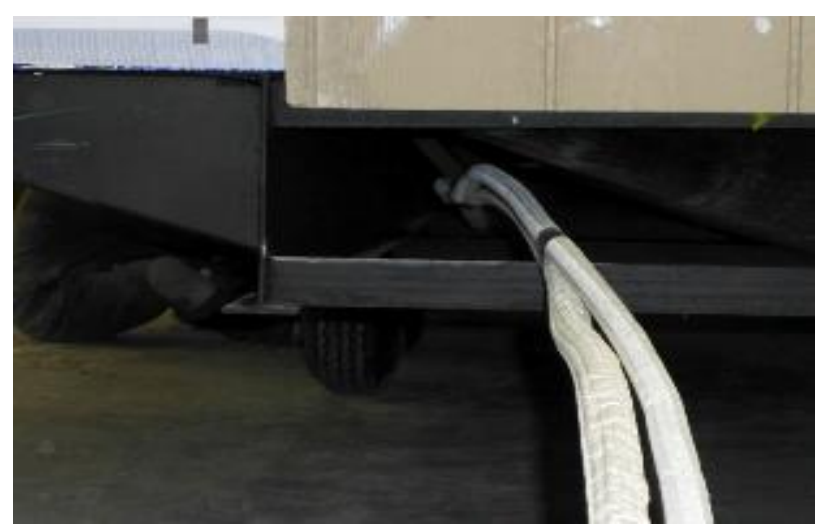

Figure 14. DHP refrigerant lines run along the chassis

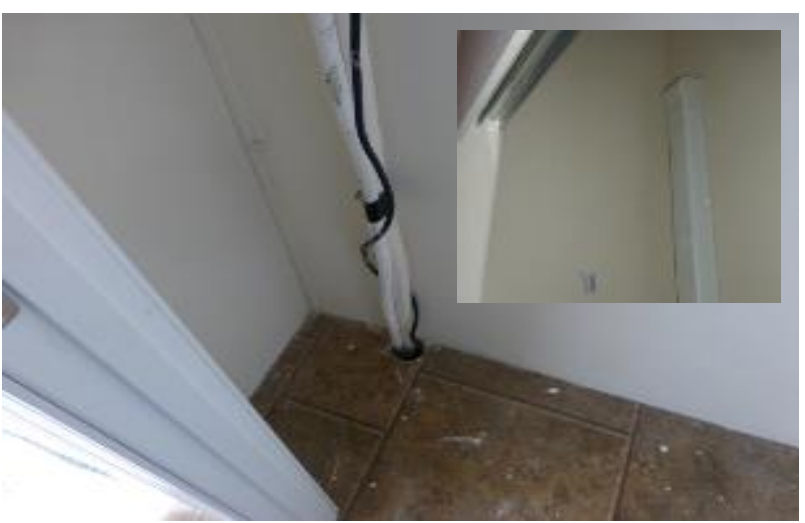

Figure 14. DHP refrigerant lines run in a closet

The indoor head must — unless absolutely impossible — be located so that the refrigerant lines can be routed inboard of the I-beam, especially if the lines must cross the axles. Passing the lines below the chassis I-beams or cross members must be avoided.

If possible, the retailer and factory should try to locate the indoor head of the DHP where it will not blow directly on the occupants. This can be achieved by facing the head toward traffic areas such as hallways and placing it away from likely sitting areas.

\subsection{Domestic Hot Water System-Heat Pump Water Heater}

An HPWH was installed in place of a typical electric tank water heater. The four prototype homes used the AirGenerate ATI-66DV (currently the only available dual-ducted NEEA Tier II qualified equipment). The project team opted to use a dual-ducted HPWH because it allowed the prototype homes to sidestep all the following issues: chilling a secondary zone where a single DHP head is supplying heating, introducing noise directly into the home (by installing the unit in an open alcove in a utility room), and needing to make up the large amount of air an HPWH would exhaust from the home if operated in a single-ducted configuration. This water heater did present some issues that required plan modifications.

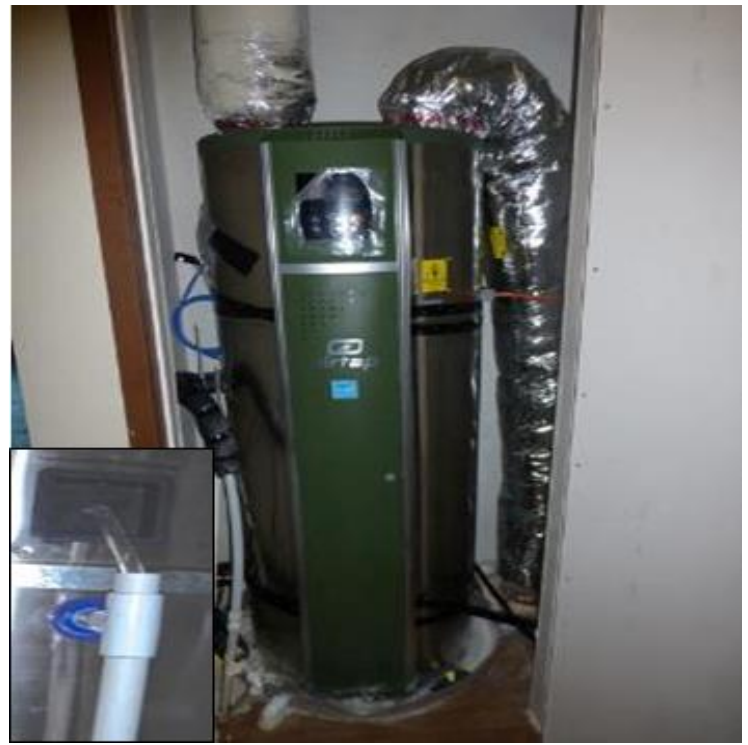

Figure 15. HPWH with ducting and condensate detail 
First, a larger water heater cabinet (unit is 25.5 in. diameter $\times 69.3$ in. tall) was necessary. The project team suggests a minimum 10-in. clearance on each side and to the rear of the unit to facilitate connections and allow space for a 6-in. intake duct behind the unit (see Figure 15). The cabinet required a swing door with a doorknob to facilitate occupant access to the water heater control panel and filter for periodic cleaning. Access above the HPWH is required because the air filter lifts upward for removal and cleaning. The added door, larger closet, intake, and exhaust ducting all increased the cost of the measure and imposed limitations on home floor plan designs.

The ATI 66-gallon water heater weighs more than $240 \mathrm{lb}$ dry. The HPWH sometimes required an added floor joist, depending upon where it was located. A 6-in. inlet metal duct penetrates through the floor behind and to the right of the unit. The joist layout must be planned to avoid joists within $12 \mathrm{in}$. from the right edge and rear of the water heater to allow room for the duct.

Factory staff plumbed the condensate pipe from the HPWH to the outside of the house with $3 / 4$-in. plastic pipe. The unit has a $3 / 4-i n$. female port on the left side for its primary condensate drain. A vinyl tube connects to the internal overflow drain and exits the unit above the primary drain. Factory staff installed a $3 / 4$-in. nipple and connected it to a tee, which allowed the overflow tube to be dropped into the top of the tee. The flex tubing was combined with the primary drain nipple and was plumbed down through the floor (see Figure 15 inset). A length of pipe was shipped with the home to allow the condensate line to be continued to outside the crawl space. Home setup instructions must call out this detail.

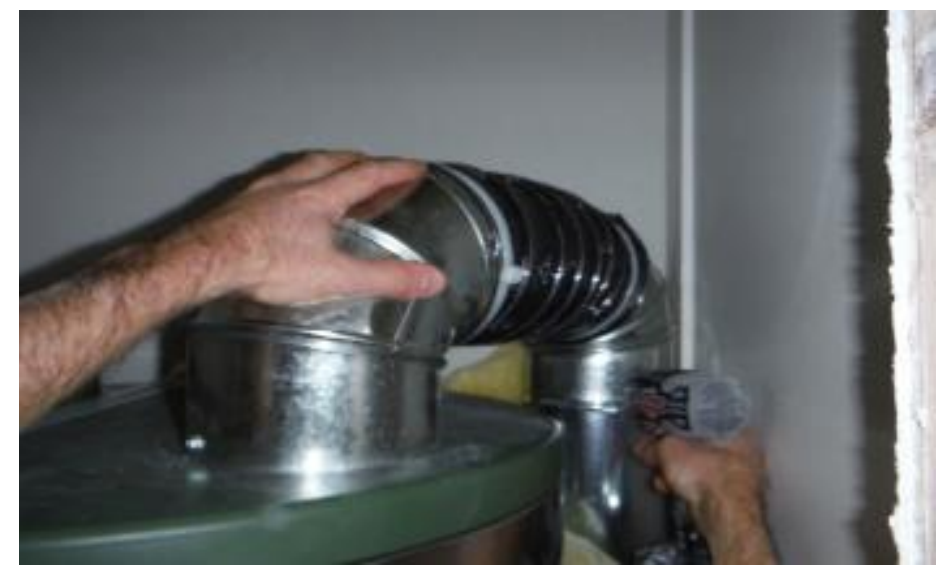

Figure 16. HPWH intake duct connection

On the intake side of the air supply on the top of the HPWH, a metal 6-in. elbow was installed to turn 90 degrees toward the right rear corner of the closet. A run of 6-in. rigid metal duct was installed from the crawl space, through the floor, up to such a height that installing a second elbow on the top of the duct brought it in line with the elbow installed on the HPWH. The two elbows were connected with a short length of flex duct (see Figure 16). The entire duct was then insulated. The insulating jacket from 6-in. flex duct (the aluminum jacketed variety is recommended) is an excellent material for providing the insulation. With the Mylar inner liner removed, a length of duct jacket can be slid over the rigid duct, bunched up, and then extended to cover the entire duct run once it has been completed. The combination of rigid metal and flexible ducting simplified lining up the ductwork and should limit the potential for vibration transmission. Factory staff installed hardware cloth or other vermin screen at the duct's bottom opening. 
On the exhaust air outlet, a 6-in. duct was run from the outlet at the top of the HPWH through an adjacent exterior wall or ceiling (depending upon water heater location). All elbows in the duct run or duct segments that pass through the building envelope were rigid ducting. Insulated flexible duct with an aluminum jacket was used in the water heater cabinet and in the attic to help line up the ductwork and prevent vibration transmission. The duct run was insulated along its full length. The exhaust duct connects to an exhaust fan "gooseneck" roof terminus or wallmount fan terminus. In no case may the exhaust side be allowed to terminate in the crawl space, a roof cavity, or in the house (process air is coming from the crawl space).

The HPWH cabinet walls were insulated if they were adjacent to a bedroom to ensure minimal noise transmission from the HPWH. During the project team's site visits to the four homes, the HPWH compressor was so quiet that project staff standing next to the HPWH in front of the open closet could not hear that the unit was operating. Because the HPWH was so quiet, project staff would eliminate the closet wall insulation requirement in future HPWH installation when using the ATI-66. Installing and insulating the intake and exhaust metal ducting was one of the more production-disrupting measures installed in this project. Plant staff expressed confidence that future installations could be done more efficiently as they gained experience.

\subsection{Results from Building High-Performance Manufactured Home Prototypes}

Partnering plants gave the project team the opportunity to build the complete HPMH package to assess the overall impact of an HPMH on the production line; the construction processes, materials, and equipment that were necessary to meet the HPMH specification; and the opportunities that are available to further refine and optimize the HPMH package. The project team created a draft checklist to assist the project team and plants with HPMH construction. It is included as Appendix A.

In six expert meetings with the region's energy-efficiency stakeholders (electric utilities and related organizations), project staff presented concrete examples of the industry's ability to supply an HPMH in today's market. Those six meetings have helped facilitate further discussion between the industry and utilities in the region.

Monitoring data from the occupied HPMH prototypes are beginning to confirm and validate the project's previous phase modeling work through assessment of the as-built homes. The project team will learn more about occupant comfort issues and ventilation system effectiveness through long-term environmental monitoring of the prototype homes. Monitoring began in January 2014 and will end in January 2016.

\subsection{Integration Opportunities}

This HPMH prototype research project was very timely. The energy-efficiency standards within the HUD FMHCSS are currently under review for improvement and are likely to be published by the end of 2015. At that time the federal requirements could rise to a level close to the current NEEM specifications, so above-code programs such as NEEM and ENERGY STAR would need to develop new specifications. This project provides strong guidance for above-code programs.

The project demonstrated that the HPMH package could be readily deployed in the manufacturing setting. The project also demonstrated that the HPMH measures can reduce energy used for space conditioning, water heating, and lighting by $50 \%$ over typical $\mathrm{MH}$ construction practice in the region. Once all four HPMHs have been monitored for at least a full year, the team should be able to assess and validate previous computer modeling of energy 
savings and cost-effectiveness analysis against monitored energy savings. This assessment and validation will give utilities the information they need to continue moving toward the creation of a new regional HPMH program. 


\section{Monitoring}

The first HPMH prototype was completed in time to collect monitoring data through much of the 2014 winter season. Figure 15 shows monthly energy use for HPMH \#1, which is sited outside Toledo, Washington, near the base of Mount St. Helens. The home is occupied full time. Annual energy use at the site likely will be about $9,000 \mathrm{kWh}$ - compared to 7,700 kWh predicted by the previous SEEM modeling work (using representative Typical Meteorological Year 3 weather data). The project team conducted this modeling work during the HPMH specification development phase. The energy use also aligns well with the BEopt prediction of 98.1 annual MBtu source energy for a typical home located in a slightly milder climate $(9,000 \mathrm{kWh} / \mathrm{y}=30.7$ $\mathrm{MBtu} / \mathrm{y}$ site *3.365 = $103.3 \mathrm{MBtu} / \mathrm{y}$ source).

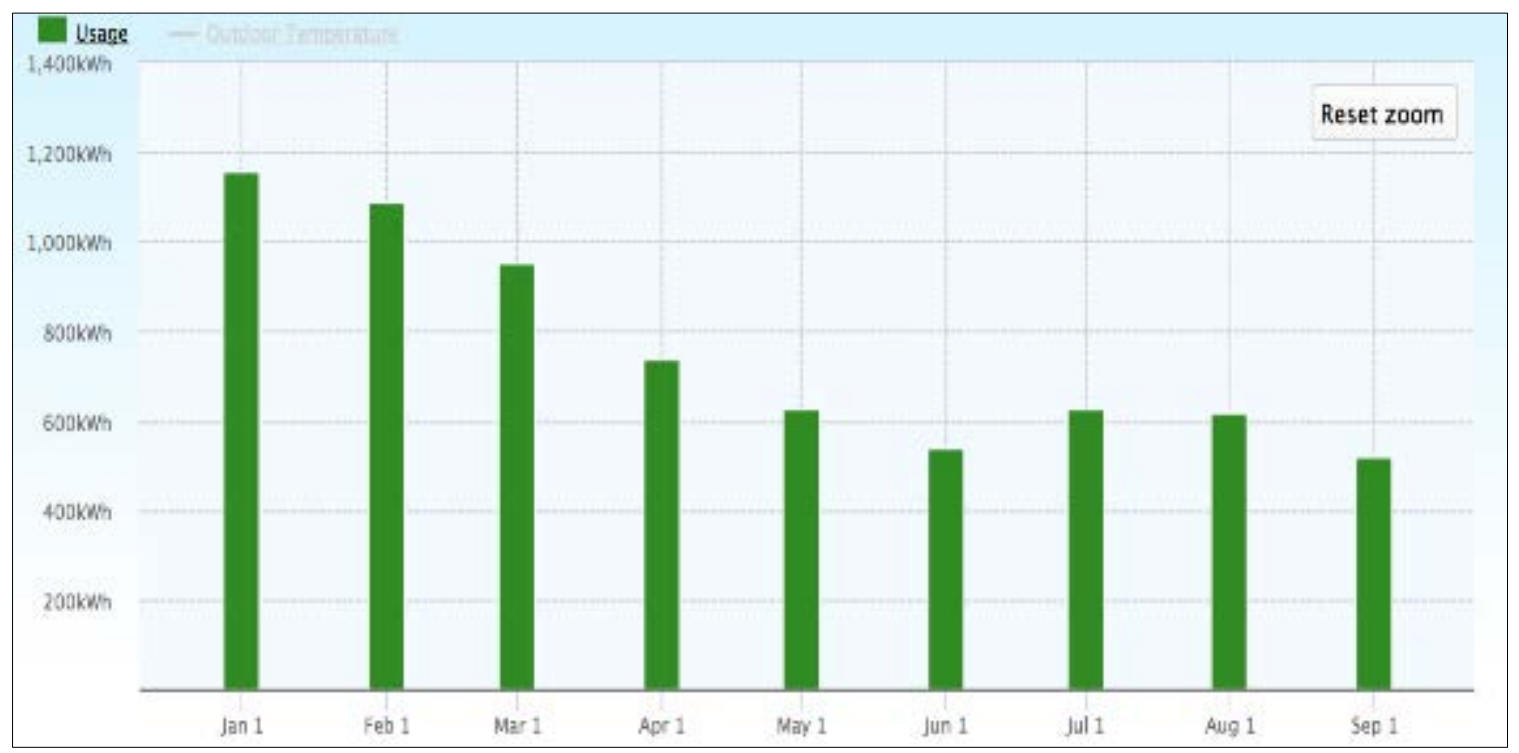

Figure 17. HPMH \#1 monthly energy use January through September 2014 (Source: SiteSage)

\subsection{High-Performance Manufactured Home Performance}

The project's previous SEEM modeling of HPWH performance required assumptions about crawl space temperature buffering versus outside temperatures, because the HPWH was being configured to draw its process air from the crawl space rather than from inside the home. The HPWH's compressor can more efficiently extract heat from warmer air, so process air drawn from the crawl space should provide a benefit compared to drawing the air from outdoors during the winter. The HPMH \#1 crawl space temperature distribution clearly indicates that the crawl space provides a significant buffer compared to outdoor air, especially in colder weather. Ecotope's preliminary findings are included in Appendix B. Figure 18 presents a summary of the hour-level data from HPMH \#1. The HPWH's impact on crawl space temperature is presented along with the magnitude of the buffer effect presented versus outdoor temperature. A "tipping point" occurs when outdoor temperature rises to about $60^{\circ} \mathrm{F}$. In warmer weather, the crawl space is cooler than the outdoors, resulting in colder incoming air to the HPWH. Once more data are collected, the project team plans to revisit this analysis and update the findings.

The HPWH units were installed to operate in such a way that electric resistance elements will turn on to prevent cool water from being delivered. In studying the data for a cold weather 
period, the HPWH met all but the most demanding hot water loads without using secondary heating elements. Even then, the elements ran only long enough to meet the immediate draw. The project team looks forward to collecting full-year data to perform a proper analysis.

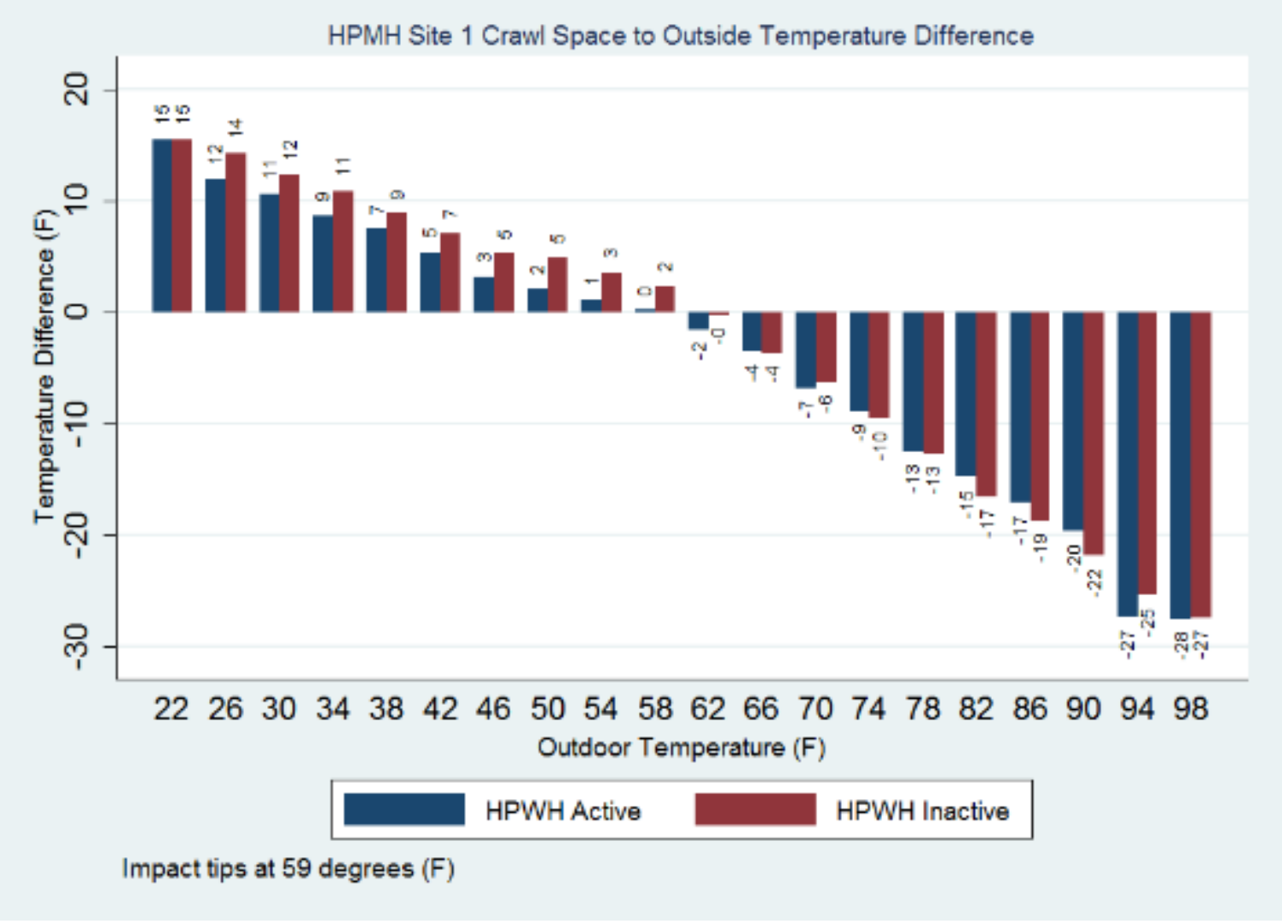

Figure 18. HPMH \#1 crawl space buffer effect (Source: Ecotope)

\subsection{Ductless Heat Pump Performance}

The project team has worked to design the DHP hybrid zonal space-conditioning system that can provide quiet, energy-efficient, and comfortable temperatures throughout the home. The system relies almost solely on the DHP's single indoor head. Using HPMH \#1 as an example, Figure 19 presents indoor room temperatures and outdoor temperatures for 3 typical winter days in early February 2014. The DHP is the only heat source that showed activity during the period, except for bathroom electric resistance heating that occurred coincident with bathing.

The data for the last week of January and the first week of February show that the outdoor temperature ranged from $18^{\circ}-51^{\circ} \mathrm{F}$, with the average temperature being about $35^{\circ} \mathrm{F}$. During that period HPMH \#1 used $313 \mathrm{kWh}$ for heating, of which the electric resistance heaters accounted for $15 \mathrm{kWh}$ (again mostly coincident with bathing) — or just 5\% of the heating energy used (and delivering about $2 \%$ of the actual heating). The room-to-room temperature spread was limited to no more than $3^{\circ} \mathrm{F}$ at any time. Clearly, the DHP is proving that it can maintain even and comfortable temperatures throughout the home, without the occupants choosing to run the secondary electric resistance room heaters. 


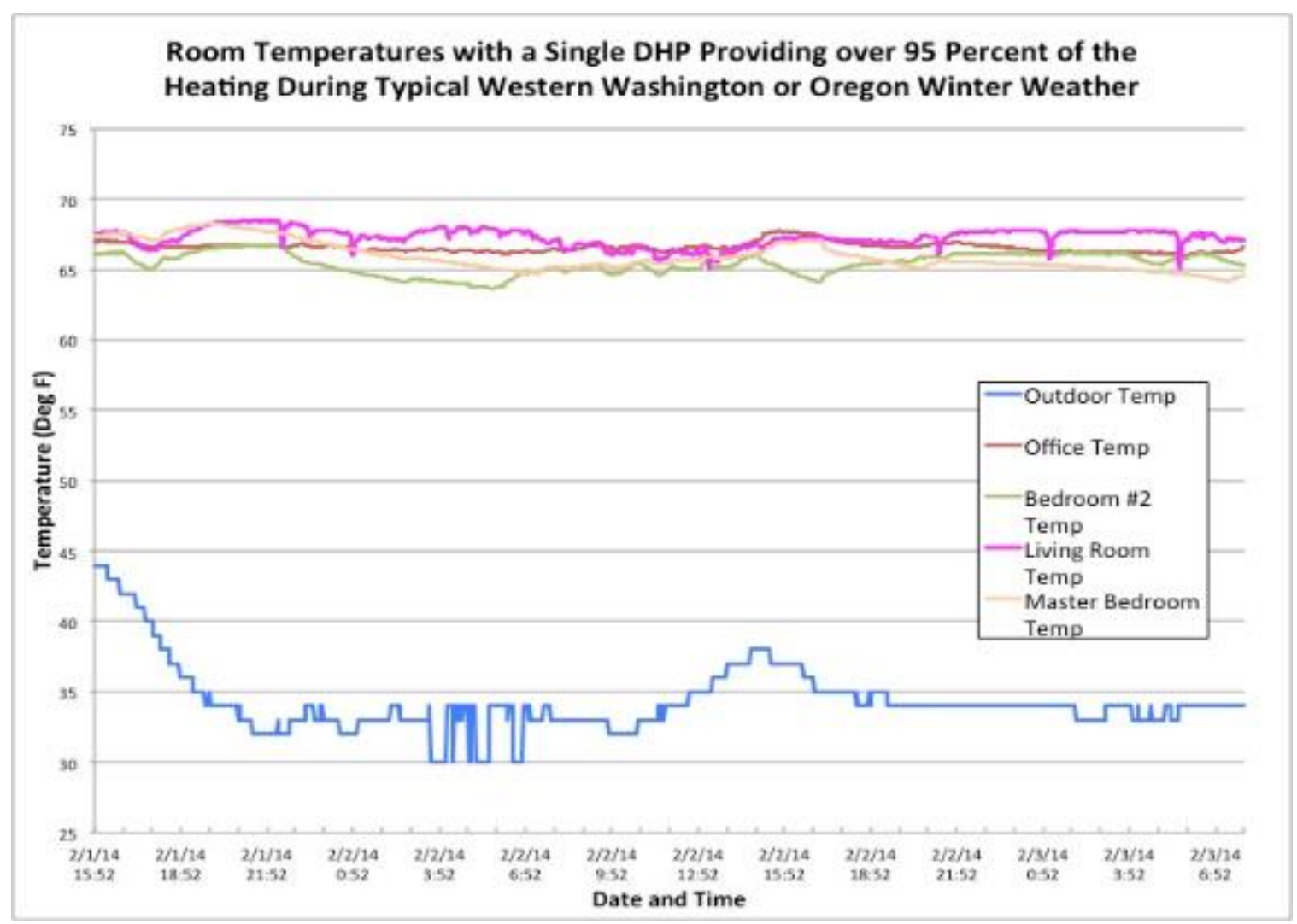

Figure 19. HPMH \#4 heating season room temperatures 


\section{Conclusions and Lessons Learned}

The DHP hybrid zonal space-conditioning system appears to be performing quite well in the HPMH prototypes. The DHPs provide nearly all space heating and maintain even temperature distributions throughout the homes. The complete system price currently appears to be a little more expensive than fitting the baseline forced-air electric furnace system with a standard efficiency heat pump, but some retailers report that the DHP system can be positioned as a premium option that comes at a very reasonable cost. The DHP is steadily gaining acceptance within the industry. One plant reports having installed more than 50 hybrid zonal DHP systems as of the end of 2013. The hybrid zonal DHP system can be adapted to many MH floor plans. The noise reduction might be a significant benefit of DHPs compared to typical MH forced-air systems. Further work is needed to develop DHP installation approaches that rely upon work performed onsite. The NEEM program and local utilities will need to be able to track and be assured of quality installation.

A fully ducted HPWH is available for purchase. The project team prototyped the dual-vented ATI-66DV HPWH in all four homes. The HPWH was an expensive piece of equipment. Installing and insulating the 6-in. intake and exhaust metal ducting made it one of the more timeconsuming measures in the HPMH prototypes built in this project. In the next four HPMHs, the General Electric GeoSpring 50-gallon HPWH will be used in place of the 66-gallon AirGenerate as a cost-reduction strategy. The General Electric HPWH requires no ducting because it uses interior air to heat the water. The non-ducted HPWH will pose its own set of challenges for incorporation into some floor plans, especially those in which the water heater is located inside a bedroom closet and away from the main zone of the home. The project team will closely observe the non-ducted HPWH in the next prototypes to discern sound, comfort, and other occupant satisfaction impacts from the equipment change.

Exterior foam sheathing increases labor at a point in construction where most plants already experience bottlenecks, so plant workstations might need to be reconfigured. The foam installation was straightforward, and the modest material thickness appears to avoid the problem of siding fasteners missing framing members. Siding is installed with nail guns using 2.5-in. nails. Nail guns can cause nails to miss studs because the nail hitting the stud through the foam has no feeling of resistance. All four prototype HPMHs built with foam sheathing for this project were transported without damage to siding or windows. The plants acknowledge that this measure saves energy, but they have not embraced it as yet because it slows the production line. The project team has envisioned a different approach to foam installation that could expedite the process and reduce the need for hand cutting the foam at window and door openings. In this approach full sheets of foam are installed up to - and then skip - a window or door opening, and resume with the next full sheet at the far edge of the skipped opening. Pieces of foam can then be cut and installed at the top and bottom of the opening. The project team plans to develop revised installation processes for testing with future HPMH prototypes.

Triple-pane windows do not appear to present any significant technical challenges except for when the additional weight of the windows might be the "last straw" that requires some home models to be built with an additional axle. The flashing treatment and extra labor to lift the windows into the window openings added an average of $4 \mathrm{PH}$ to the labor on the HPMH. All the homes were delayed because of the lead time in custom ordering the HPMH window packages. Through discussions with the MH plants' typical window suppliers, the project team learned 
about the potential to bring to market dual-pane windows with performance levels close to R-4 at significantly less cost than for triple-glazed units.

Improving attic and floor insulation proved to be possible using commonly available materials. Nominal R-60 attic values were achieved in some cases. Nominal floor R-values of R-52 (belly)/R-32 (outrigger) were achieved. Installing the extra insulation took $4 \mathrm{PH}$. The attention to detail required to meet the HPMH specifications would require significant and ongoing oversight to institutionalize the processes at the plants. The project team and plant staff were able to refine and alter the original construction processes to potentially reduce the time required to achieve the desired detailing in a couple of areas, especially in the attic.

The actual cost of each HPMH prototype was tracked in this project. The average "hard" costs across the four HPMH prototypes were \$12,400 incremental above the cost of an ENERGY STAR energy package, without the markup that otherwise would be included in the factory's wholesale price to the retailer. The retail price to the consumer could be as high as $\$ 24,000$ more than an ENERGY STAR energy package depending on how the factory and retailer set the price of the HPMH option. As of the writing of this report, two potential buyers have independently requested the HPMH package from the industry. The project's previous estimate of "hard" costs from late 2011was $\$ 10,000$. Window costs and HPWH costs were markedly higher than the initial estimates. While one reasonably could expect the cost to build an HPMH to decrease significantly with repetition, its price will remain high enough to affect regional adoption. This cost factor could make it more difficult to secure a mortgage. Optimizing the HPMH package to reduce the costs will be a focus of the next phase of the project.

The average extra PH experienced in the building of the HPMH prototypes are: $2 \mathrm{PH}$ floors; 2 PH walls (foam); 2 PH baffling and insulating ceilings (largely because the higher R-value requires significantly more insulation blowing time); 4 PH on windows and doors-because of flashing and an extra person to help lift windows; 6 PH HPWH electrical, cabinet redesign, duct installation, drop and media box monitoring, condensate plumbing, miscellaneous (likely about 2-3 PH for the HPWH installation). In total, sixteen additional PH were required to build each prototype HPMH, and that labor direct cost is included in the overall average direct incurred costs of $\$ 12,400$ across all four plants. Sixteen PH extra labor accounts for $20 \%$ of the extra costs, or about $\$ 2,400$. In all cases the building of an HPMH was the first time plant personnel installed these measures. If this were to become a routine upgrade for the plants, the hours should decrease.

The project team built four HPMHs and modeled an HPMH package to determine the energy savings $(8,000-11,000 \mathrm{kWh}$ for each $\mathrm{HPMH}$, or 50\% savings over a current practice HUD code home).

Preliminary energy use data from an occupied HPMH has been monitored through most of the 2013-2014 heating season. Monitored data compare well to SEEM and BeOpt estimates so far, suggesting that the defined HPMH measure package is likely to achieve the $50 \%$ energy savings over the HUD code baseline target. 


\section{References}

Engebrecht Metzger, C.; Wilson, E.; Horowitz, S. (2014). Addendum to the Building America House Simulation Protocols. Golden, CO: National Renewable Energy Laboratory, NREL/TP5500-57450.

Greer, R.; Hewes, T.; Peeks, B. (2004). Northwest Energy Efficient Manufactured Housing Program In-plant Inspection Manual. Salem, OR: Oregon Department of Energy.

Hewes, T.; Peeks, B. (2011). Field Monitoring of Two Manufactured Homes in the Pacific Northwest. Prepared for the U.S. Department of Energy Building America Program under contract to PNNL. Corvallis, OR: Northwest Energy Works. 


\section{Bibliography}

Baylon, D.; Davis, B.; Hewes, T. (March 2009). Summary of NEEM Manufactured Home Field Data and Billing Analysis. Seattle, WA: Ecotope, Inc.

Baylon, D.; Davis, B.; Palmiter, L. (1995). Manufactured Home Acquisition Program: Analysis of Program Impacts. Prepared for the Bonneville Power Administration. Seattle and Olympia, WA: Ecotope, Inc. and Washington State Energy Office.

Baylon, D.; Lubliner, M.; Davis, B.; Kennedy, M. (1990). Manufactured Homes Cost Data Analysis Report. Prepared for the Bonneville Power Administration. Seattle and Olympia, WA: Ecotope and Washington State Energy Office.

Code of Federal Regulations. (2001). "Manufactured Home Construction and Safety Standards." Title 24, Part 3280.

Eklund, K.; Gordon, A. (2011). “Cost Assessment for Manufactured Homes.” Prepared for the Bonneville Power Administration. Olympia, WA: Washington State University Extension Energy Program.

Eklund, K.; Gordon, A.; Lubliner, M. (January 31, 2011). Strategic Recommendations to Improve Energy Efficiency in Manufactured Housing. A Report to the Bonneville Power Administration. Olympia, WA: Washington State University Extension Energy Program.

Hewes, T.; Peeks, B. (December, 2012). High Performance Manufactured Home Project: Final Project Report. Prepared for Bonneville Power Administration. Corvallis, OR: Northwest Energy Works.

Hewes, T.; Peeks, B; (January 2013) Northwest Energy Efficient Manufactured Housing Specification Development. Prepared for the U.S. Department of Energy Building America Program under contract to Florida Solar Energy Center. Corvallis, OR: Northwest Energy Works.

Hewes, T.; Peeks, B. (2011). State of the Industry Report. Prepared for the Bonneville Power Administration. Corvallis, OR: unpublished report.

Hewes, T.; Peeks, B. (January 18, 2012). Personal communication with Robin LeBaron, Deputy Director of Fair Mortgage Collaborative.

Kessler, B.; Levy, E.; Mullens, M.; Rath, P.; Tompos, E. (April 2012). "Expert Meeting Report: Advanced Envelope Research for Factory Built Housing." Prepared for the U.S. Department of Energy Building America Program under contract to NREL, New York, NY: The Levy Partnership, Inc.

Larson B; Hadley, A; Harris, J. (2012). "Heat Pump Water Heaters: Tier 2 - Ducted Interior Installations." Presented to the Pacific Northwest Regional Technical Forum February 14, 2012, by Adam Hadley and Jeff Harris, Portland, OR. Accessed August 6, 2013, 
at http://rtf.nwcouncil.org/meetings/2012/02/HPWH_Ducted Interior_Installations Provisional Proposal 021412 v5.pptx

Northwest Energy Efficiency Alliance (NEEA). (November 7, 2011). "A Specification for Residential Heat Pump Water Heaters Installed in Northern Climates, Version 4.0." Portland, OR: NEEA.

NEEM. (2011). Northwest Energy Efficient Manufactured Housing Program Database. Corvallis, OR: Northwest Energy Works.

Northwest Power and Conservation Council. (2010). Sixth Northwest Conservation and Electric Power Plan. Portland, OR: Northwest Power and Conservation Council.

Widder, S.H.; Petersen, J.H.; Parker, G.B.; Baechler, M.C. (2014). "Impact of Ducting on Heat Pump Water Heater Space Conditioning Energy Use and Comfort.” PNNL-23526, Pacific Northwest National Laboratory, Richland, WA. 


\section{Appendix A. High-Performance Manufactured Home Quality Checklist}

\begin{tabular}{|c|c|c|}
\hline HPMH Quality Criteria & In-Plant & NEEM \\
\hline \multicolumn{3}{|l|}{ Home Design, Documentation and Certification } \\
\hline $\begin{array}{l}\text { DHP electric resistance hybrid zonal system: DHP in-plant } \square \\
\text { DHP-ready } \square\end{array}$ & By: & By: \\
\hline DHP equipment and zonal heater sizing & By: & By: \\
\hline $\begin{array}{l}\text { Roof Truss has adequate attic depth to achieve R- } 49 \text { - check with } \\
\text { NEEM staff }\end{array}$ & By: & By: \\
\hline $\begin{array}{l}\text { Water heater closet sized to fit HPMH and ducts to } \\
\text { crawlspace/outside }\end{array}$ & $\square$ By: & $\square$ By: \\
\hline $\begin{array}{l}\text { DAPIA Package includes HPMH insulation, space \& water heating } \\
\text { requirements }\end{array}$ & $\square$ By: & $\square$ By: \\
\hline $\begin{array}{l}\text { Setup instructions give clear direction for installing condensate } \\
\text { drain(s) for DHP (if factory installed) and HPWH, specify skirting } \\
\text { notch out for DHP lines (if needed) }\end{array}$ & By: & By: \\
\hline HUD data plate contains accurate u-values & By: & By: \\
\hline $\begin{array}{l}\text { NEEM Home Certificate shows HPMH path and included in } \\
\text { Homeowner Packet }\end{array}$ & By: & By: \\
\hline \multicolumn{3}{|l|}{ Floor Construction. R-38 effective } \\
\hline $\begin{array}{l}\text { Blown-in Cellulose: R-11 blanket under whole floor, blown over-full, } \\
\text { outrigger area tamped and all raked level (min. } 13 \text { in. depth at floor } \\
\text { center), boxed-in drops OR }\end{array}$ & $\square$ By: & $\square$ By: \\
\hline $\begin{array}{l}\text { Fiberglass blanket / batt: R-11 blanket under whole floor, } 2 \text { more R- } \\
11 \text { blankets between I-beams, R-19 (or higher) batts in joist bays } \\
\text { from rim to rim }\end{array}$ & $\square$ By: & $\square$ By: \\
\hline \multicolumn{3}{|l|}{ Wall Construction. } \\
\hline $\begin{array}{l}\text { R-21+R-5 foam sheathing } \square \text { R-22HD+R-3 foam \& insulated } \\
\text { headers } \square \\
2 \times 8 \text { @ } 24 \text { " o.c. with R-25 \& ins. headers } \square 2 \times 8 \text { @ 16" o.c. with R- } \\
30 \mathrm{HD} \square\end{array}$ & By: & $\square$ By: \\
\hline Grade I Insulation Installation (no voids or compression) & By: & By: \\
\hline $\begin{array}{l}\text { Weather Resistant Barrier: Building Wrap } \square \text { Taped Foam } \\
\text { Sheathing } \square\end{array}$ & $\square$ By: & By: \\
\hline $\begin{array}{l}\text { Siding fasteners have adequate length to account for foam } \\
\text { sheathing }\end{array}$ & $\square$ By: & $\square$ By: \\
\hline $\begin{array}{l}\text { Windows } U=.22 \text {-adequate length fasteners- pan head screws, } \\
\text { roofing nails }\end{array}$ & $\square$ By: & $\square$ By: \\
\hline \multicolumn{3}{|l|}{ Ceiling Construction. R-49 effective } \\
\hline Baffles installed to cover wall top plate and extend until R-49 depth & By: & By: \\
\hline Insulation blown-in under baffles and packed to fill all voids & By: & By: \\
\hline Attic evenly blown to R-49 depth & By: & By: \\
\hline
\end{tabular}




\begin{tabular}{|l|l|l|}
\hline Mechanical Systems, Lighting, Appliances, Water Efficiency & & \\
\hline $\begin{array}{l}\text { Water Heat: Heat Pump Water Heater NEEA Spec. Tier 2 } \square \text { dual- } \\
\text { ducted } \square\end{array}$ & $\square$ By: & $\square$ By: \\
\hline $\begin{array}{l}\text { Whole House Exhaust Fan - 32 watt max, rated for continuous } \\
\text { operation }\end{array}$ & $\square$ By: & $\square$ By: \\
\hline $\begin{array}{l}\text { Bathroom Ventilation heat light combo doesn't use heat lamps for } \\
\text { illumination }\end{array}$ & $\square$ By: & $\square$ By: \\
\hline $\begin{array}{l}\text { Lighting: 90\% of sockets have CFLs or LEDs installed or shipped } \\
\text { with home }\end{array}$ & $\square$ By: & $\square$ By: \\
\hline Energy Star Appliances: Dishwasher $\square$ Refrigerator $\square$ & $\square$ By: & $\square$ By: \\
\hline $\begin{array}{l}\text { Water: 1.75 GPM Shower Heads; bath faucets 1.0 GPM; kitchen } \\
\text { faucet 1.5 GPM }\end{array}$ & $\square$ By: & $\square$ By: \\
\hline
\end{tabular}

In-Plant QC Inspector: Date:

NEEM In-Plant Inspector: Date: 


\section{Appendix B. High-Performance Manufactured Home Crawl Space Buffer Effect Validation}

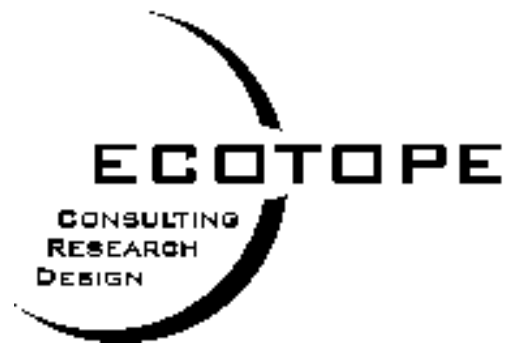

ADSG פTH AVENUE NE geATtLe, WA 9 G105

[206] 322-3753 FAX: \{2ם6] 325-727ם

Date: December 08, 2014

To: $\quad$ Brady Peeks, Northwest Energy Works, Inc.

From: Jeffrey Uslan, Ben Larson, Ecotope, Inc.

Re: High Performance Manufactured Homes - Measured and Modeled Crawl Space

Temperatures

In support of analysis for high performance manufactured homes (HPMH) Ecotope has compared measured data provided by Northwest Energy Works to prototype modeled energy output. We discuss the inputs required for the simulation models of HPMH and their output compared to the measured data at three sites. The models discussed are from SEEM (Simplified Energy Enthalpy Model). Specifically, we address the ability of the simulation to model crawl space temperatures. We further assess the impact of the operating heat pump water heater (HPWH) on crawl space temperature and the buffering effect of the crawl space on the HPWH intake air.

For the data currently available, the analysis shows good agreement between measured and modeled crawl space temperatures. Further, it shows the crawl space temperature moves closer to the ambient air temperature whenever the HPWH is running. When operating, the water heater, in this configuration, draws air from the crawl space which increases the overall air change rate of that space. Last, the measured data show a distinct advantage to drawing air for the HPWH from the buffered crawl space as opposed to directly from outdoors.

The recently monitored HPMH sites do not yet encompass an entire year of data. An annual simulation, by default covers an entire year of data with a typical weather year as an input. To compare the measured and modeled data, albeit imperfectly, we used only hours of the year held in common between the two data sets. For example, if the measured data was for hours 744 to 2880 of the year (February through April), we excluded hours outside that range from the simulation output for comparison purposes. This is surely imperfect but it will roughly compare the same seasons. 


\section{Outside Air Temperature}

Before we can make any useful comparisons between the measurements and model, we need to assess how similar the weather is between the two. A primary input to SEEM, indeed any annual energy use simulation, is the Typical Meteorological Year (TMY) weather profile for the location. The simulation is unable to take a specific weather file so if the observed year in the field is drastically warmer or colder than the TMY data, we won't ever expect the simulated crawl space temperatures to match the measured ones.

The HPMH sites are located in Toledo, WA; Pullman, WA; and Otis, OR. Proximate TMY profiles are available for the Toledo and Pullman sites (Olympia, WA and Pullman, WA); however there is not a nearby TMY file available for the Otis site. The TMY profile from Astoria, OR was selected as the closest to Otis but, it should be noted that, while the closest site geographically, Astoria is over 80 miles away and on the Pacific coast while Otis is inland. Consequently, comparisons between real, measured data and simulated data are challenging at best for this site. We examine each of the three locations in turn.

The graph below (Figure 1) compares the Toledo site's measured outside temperature and the TMY outside temperature. While the measured data has a tail extending into higher temperatures the general distribution of temperature is appropriate to continue comparing output.

Figure 1. Toledo Modeled Outside Temperatures

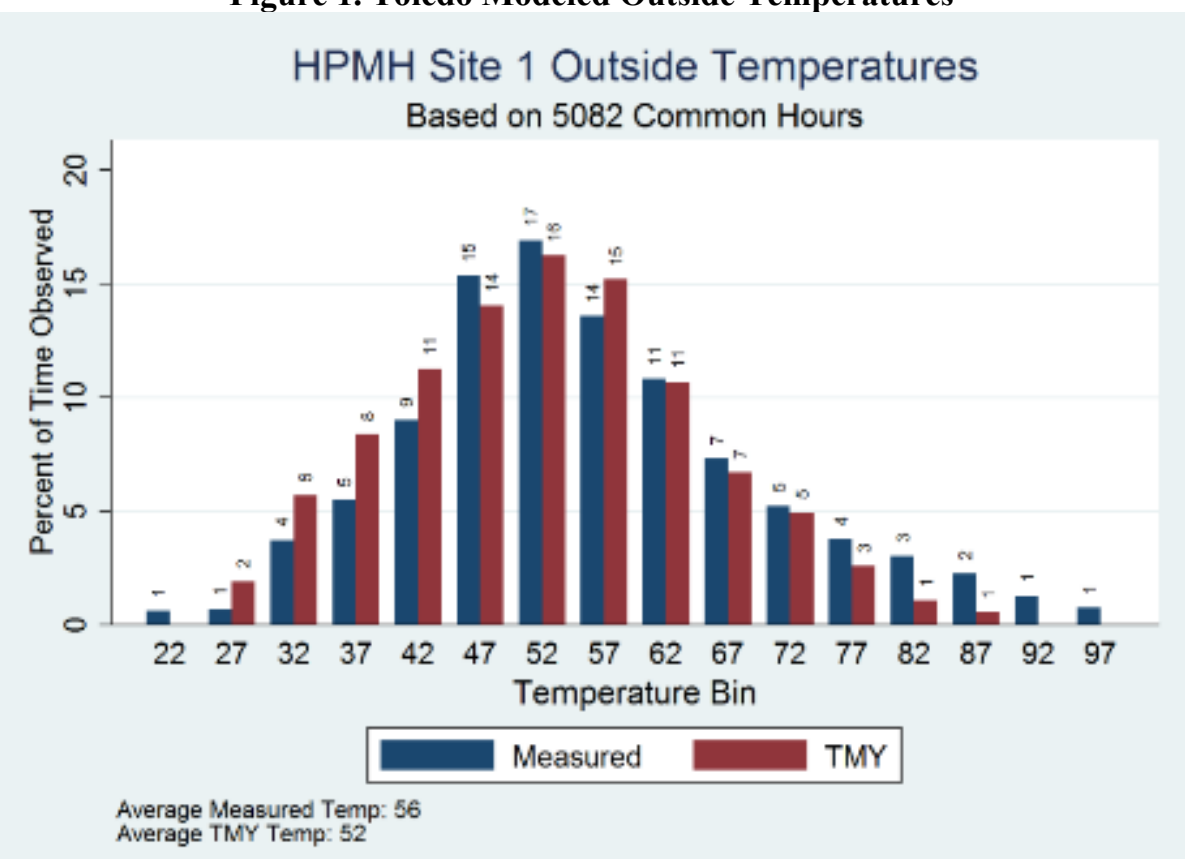

The graph below (Figure 2) compares the Pullman site's measured outside temperature and the TMY outside temperature. The TMY site matches the measured data well and is suited for further analysis. The average temperatures agree and the distributions are similar with small exceptions at the $42 \mathrm{~F}, 52 \mathrm{~F}$, and $67 \mathrm{~F}$ temperature bins. 


\section{Figure 2. Pullman Modeled Outside Temperatures}

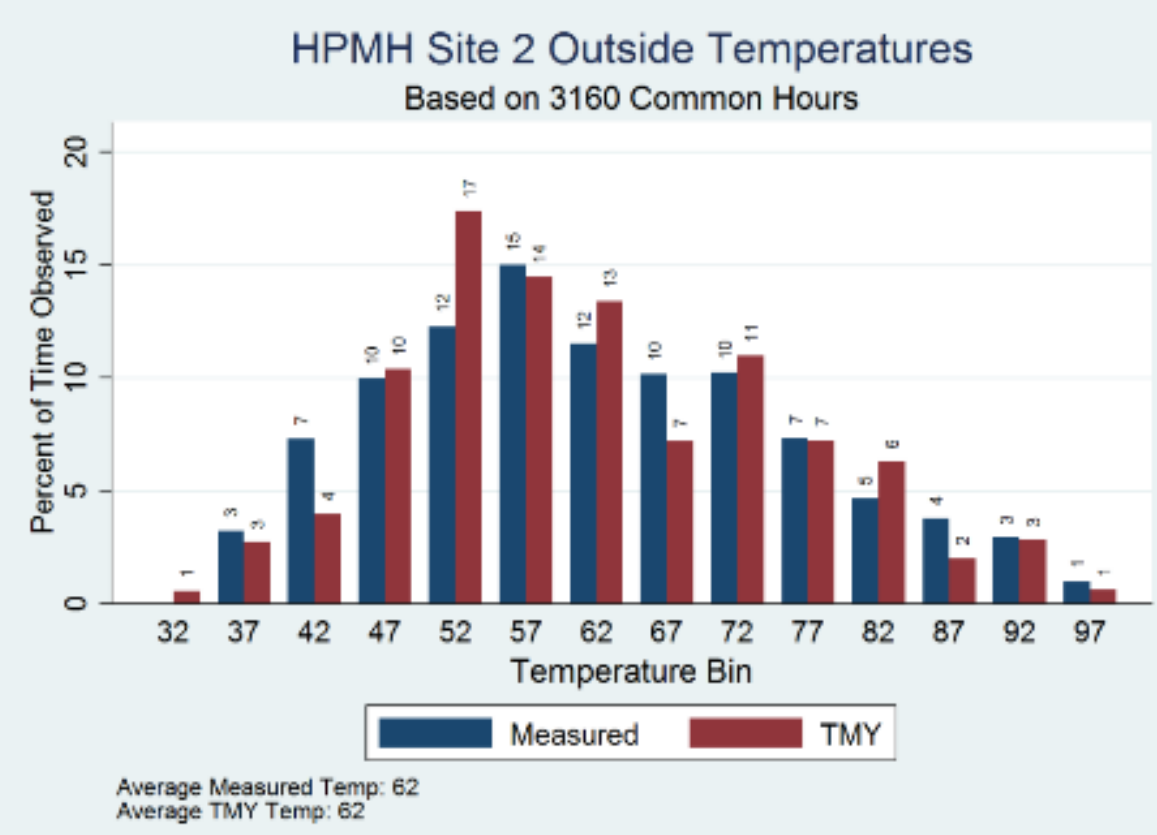

Figure 3 compares the Otis site's measured outside temperature and the Astoria TMY outside temperature. The figure shows that, as expected, the Astoria TMY file, although the best candidate to represent the site, does a poor job. Consequently, although we can compare measured and modeled results, we don't expect them to agree because we lack appropriate weather inputs for the model. For completeness, we include the comparison below but the reader should refrain from drawing significant conclusions from this site.

Figure 3. Otis Modeled Outside Temperatures

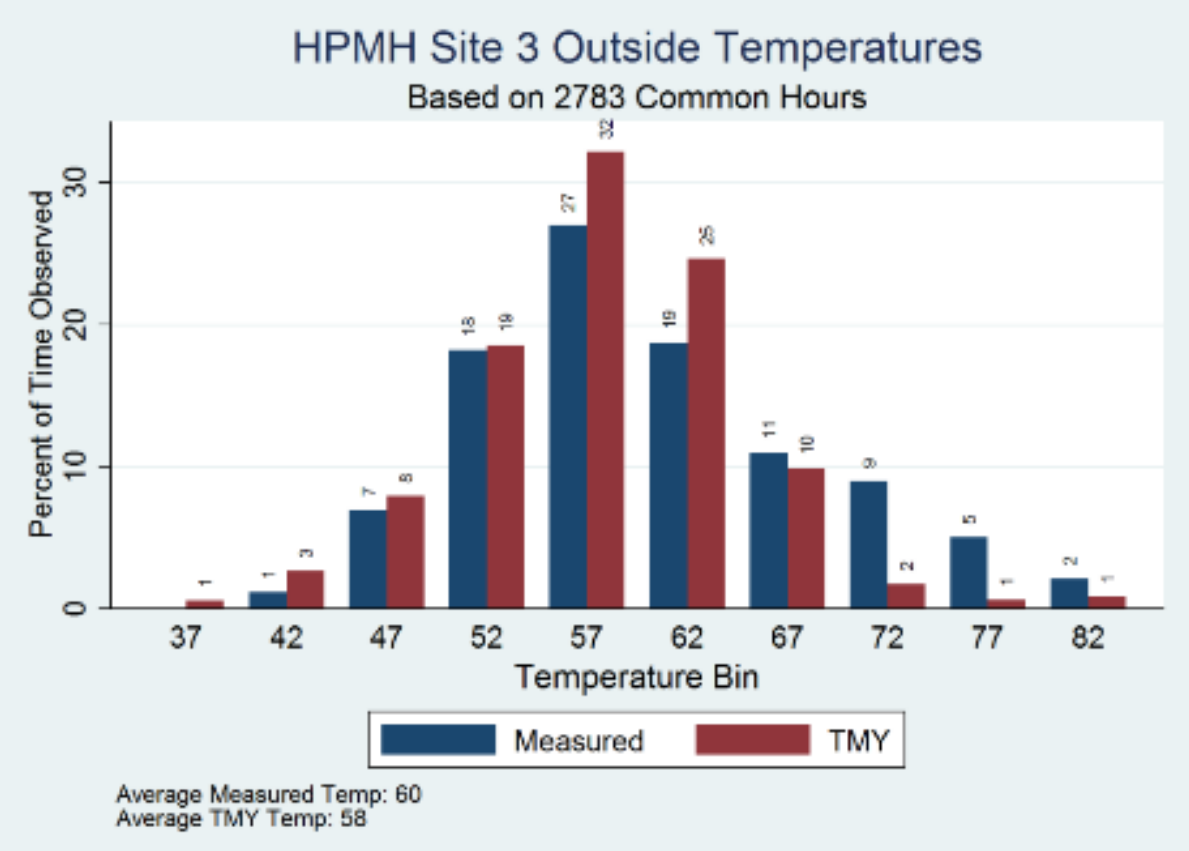




\section{Crawl Space Temperature}

Having assessed the validity of the temperature inputs we find that the two sites, where we have appropriate TMY data to compare to the observed outdoor air temperature, show remarkable agreement between the measured and modeled crawl space temperatures. Figure 4 compares the Toledo site's measured crawl space temperature and modeled crawl space temperature. Not only do the distributions in Figure 4 appear similar, the shift in average temperature is also in the same direction as the average temperature difference between the TMY data and the observed temperature. In other words, the difference in average temperature between the two happens in exactly the expected direction.

Figure 4. Toledo Modeled Crawl Space Temperatures

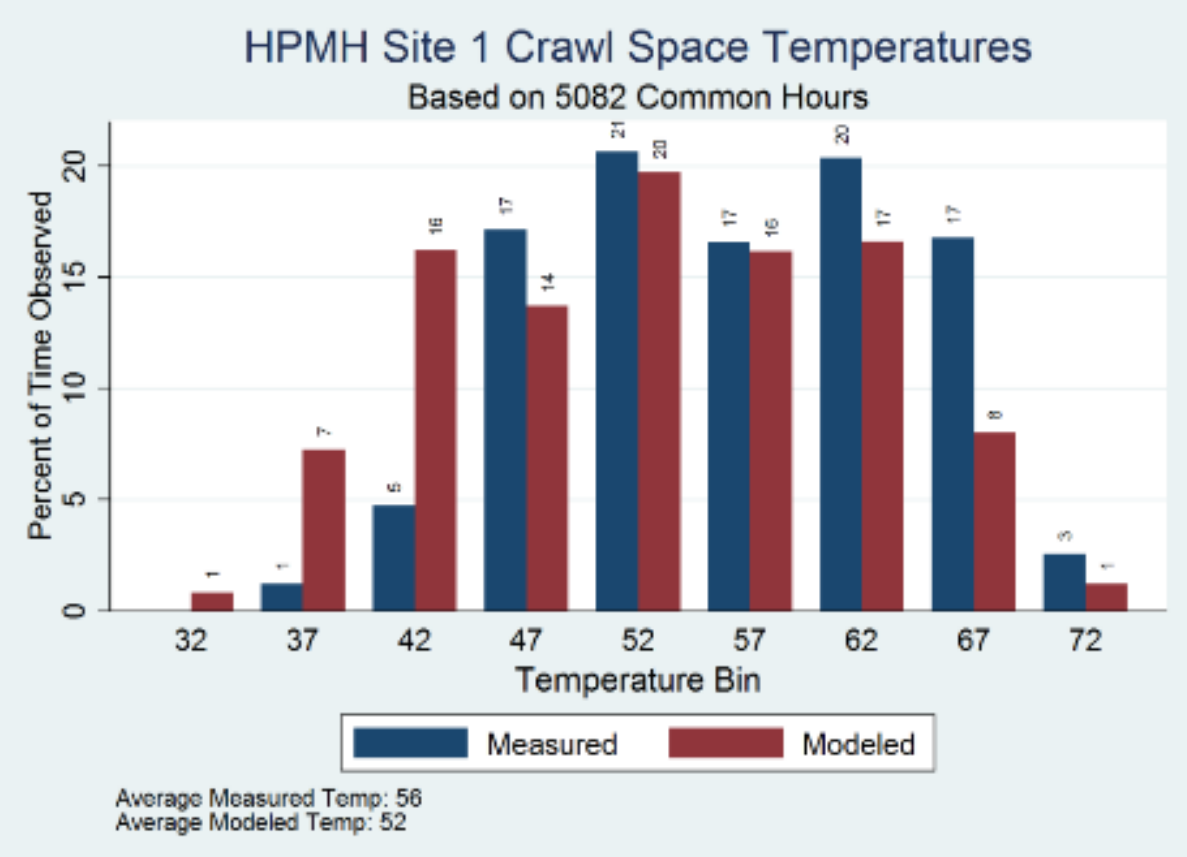

At the Pullman site, where we have good agreement between observed outdoor temperature and the TMY temperature, the crawl space modeled temperature has excellent agreement with the measurement (Figure 5). 
Figure 5. Pullman Modeled Crawl Space Temperatures

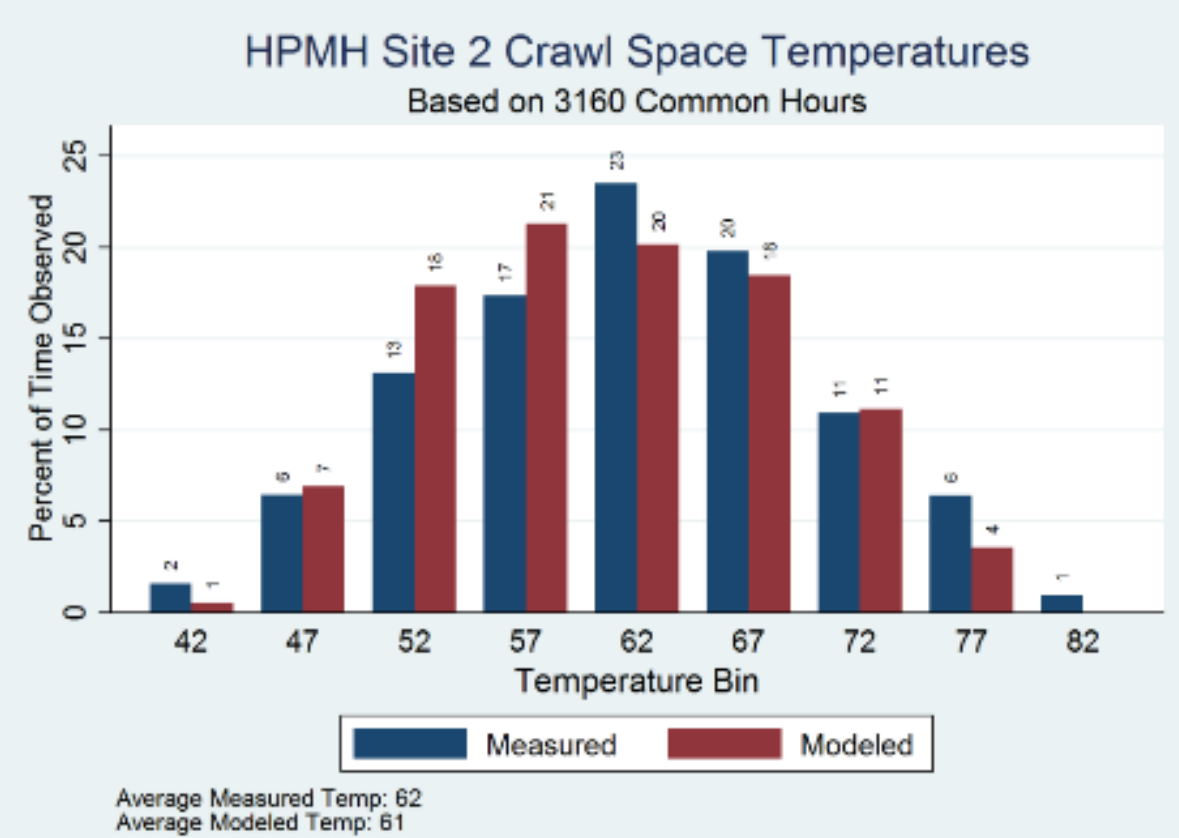

As predicted, based on dissimilarities in measured versus TMY outdoor temperature, the Otis site's measured crawl space temperature is dissimilar to the modeled Astoria crawl space temperature (Figure 6).

Figure 6. Otis Modeled Crawl Space Temperatures

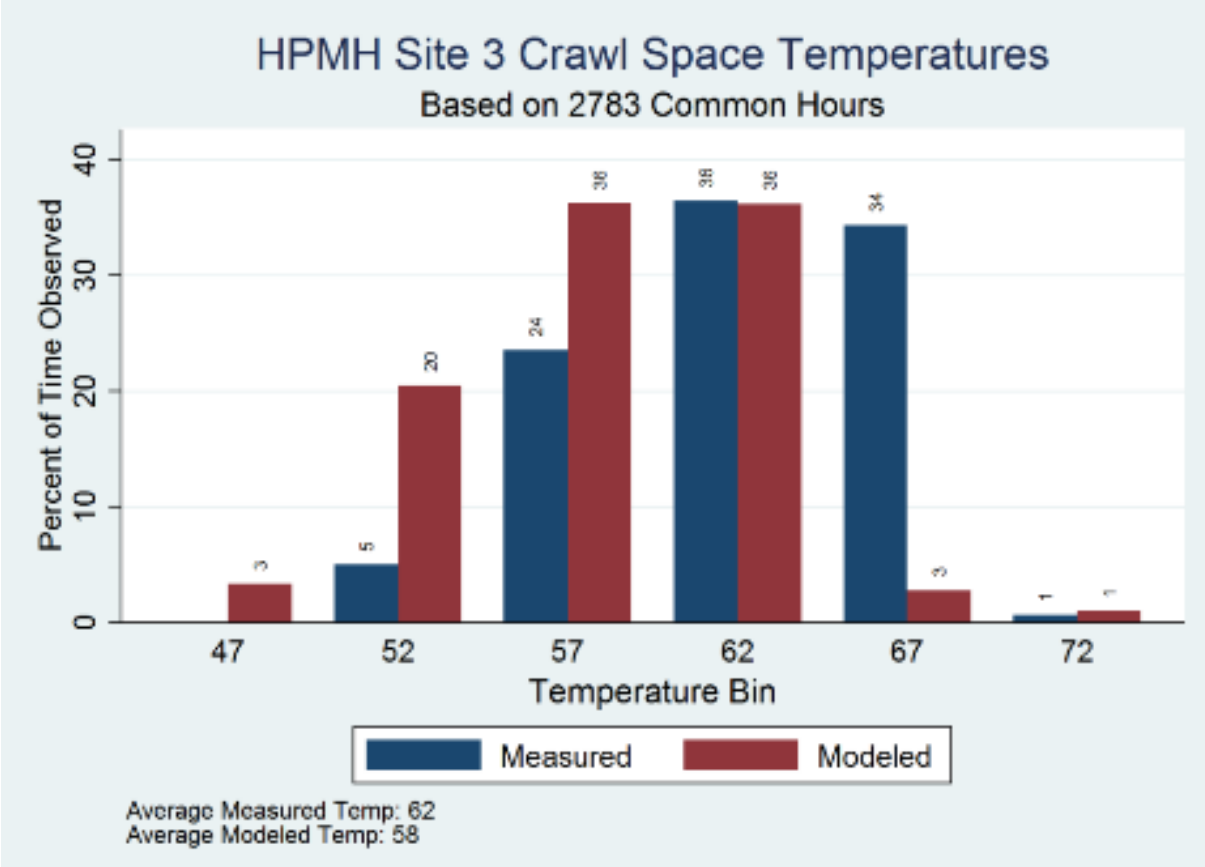




\section{Heat Pump Water Heater Impact on Crawl Space Temperature}

The heat pump water heater (HPWH) is configured with inlet and outlet ducting. The inlet draws air from the crawl space and then exhausts it outside. Therefore, when the HPWH runs, we expect to see more air flowing through the vented crawl space. Consequently, the crawl space air temperature should move closer to the outside air temperature. The simulation runs on an hourly basis which, by default, forms the interval over which we can compare the data.

Figure 7 compares the crawl space temperatures at the Toledo site when active and inactive. A slight difference of modes can be seen at 51 degrees when the HPWH is active and at 65 degrees when the HPWH is inactive. There is a measured 2 degree drop seen with HPWH activation. The observed time period was during cooler outside air temperatures. Had it been warmer outside, we would expect that HPWH activation would increase the crawl temperature.

Figure 7. Toledo HPWH Impact

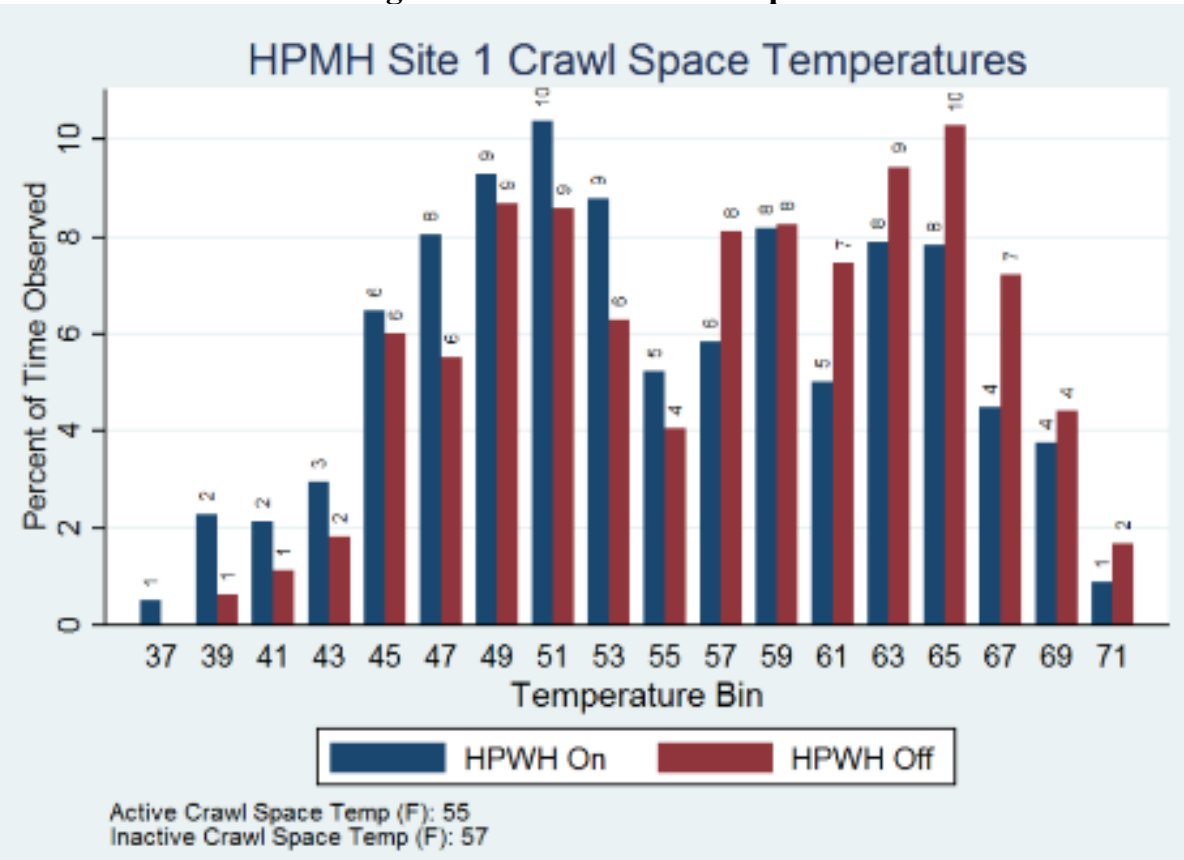

Figure 8 compares the crawl space temperatures at the Pullman site when active and inactive. There is a measured 1 degree drop seen with HPWH activation for the time period observed. 
Figure 8. Pullman HPWH Impact

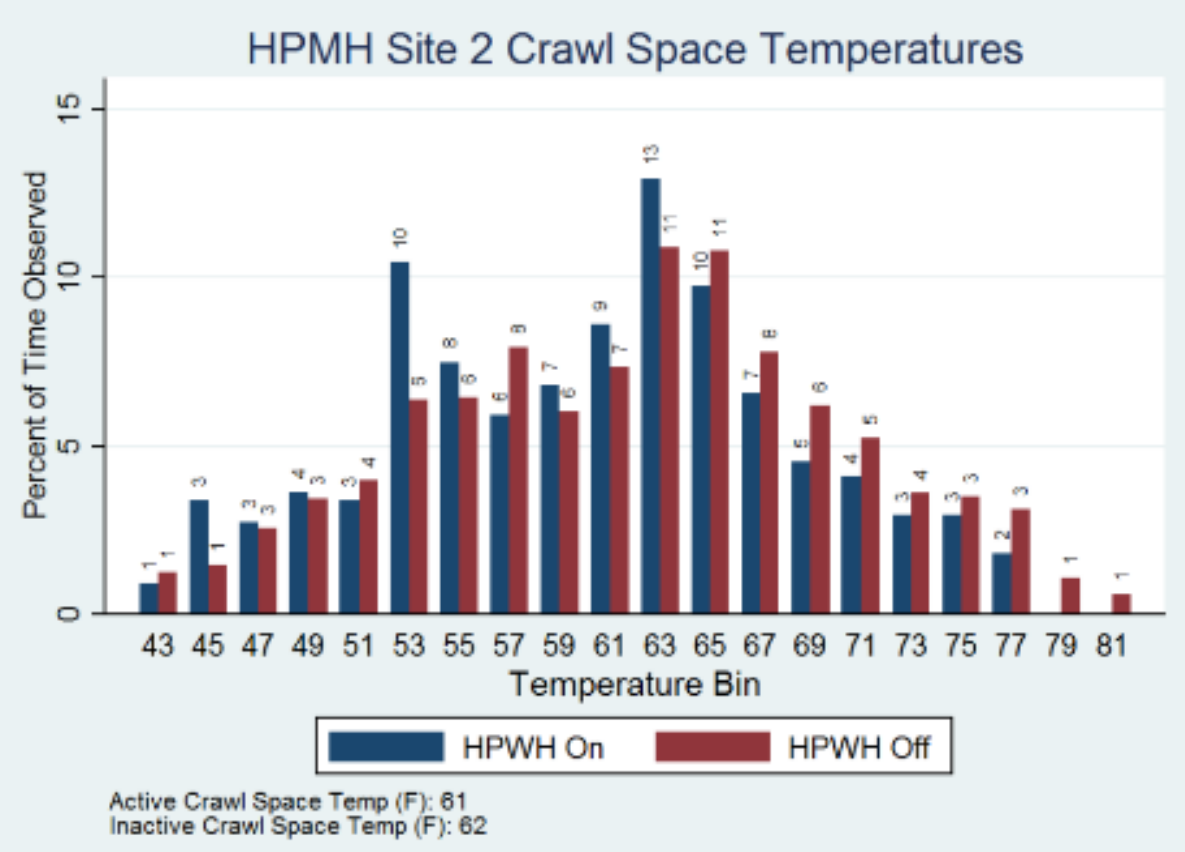

A more generalized view of the crawl space temperature buffering effect is shown in Figure 9 through Figure 11. The figures show the moderating effect of the crawl space (largely due to the ground) as the outdoor temperatures become more extreme. The tipping point for temperature is generally around $60 \mathrm{~F}$. For every two degrees below that point in outdoor temperature, the crawl space remains roughly one degree warmer. This is generally true even if the HPWH is running although the graphs clearly show the added airflow decreases the temperature difference between crawl and outside air.

Figure 9. Toledo Crawl Space Buffering Effect

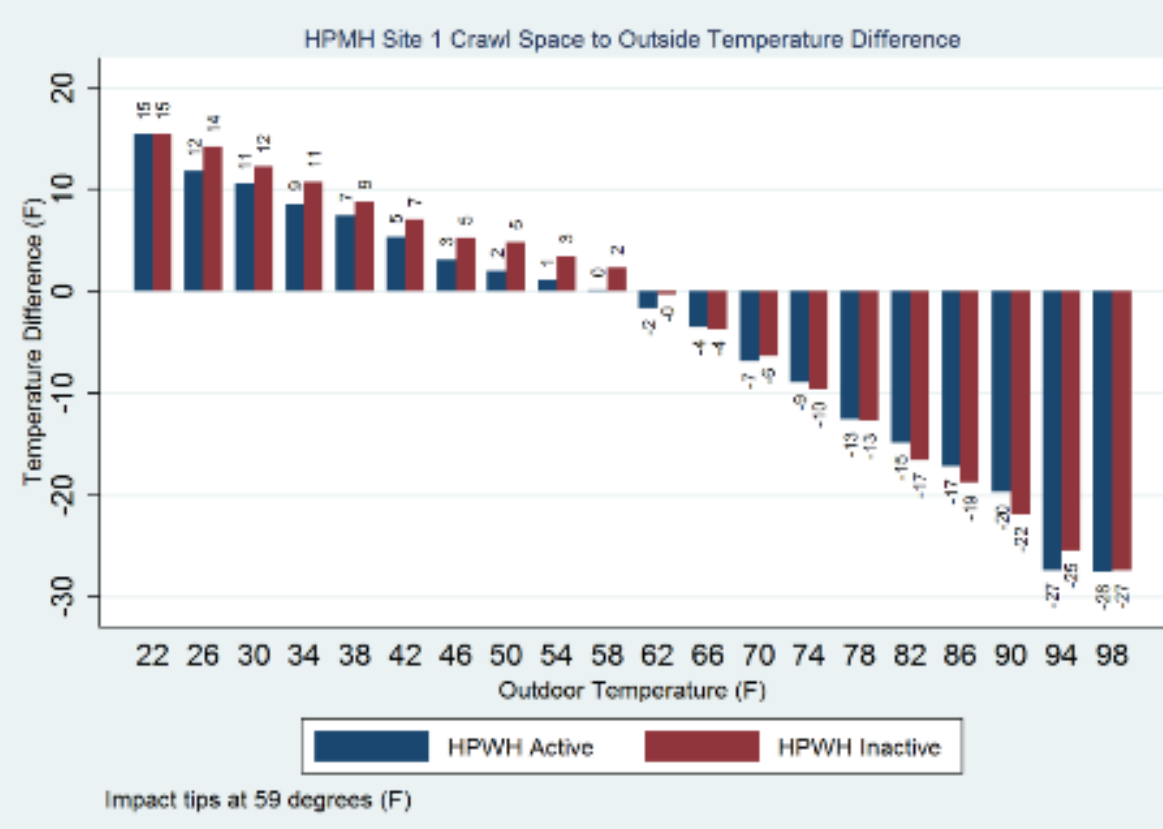


Figure 10. Pullman Crawl Space Buffering Effect

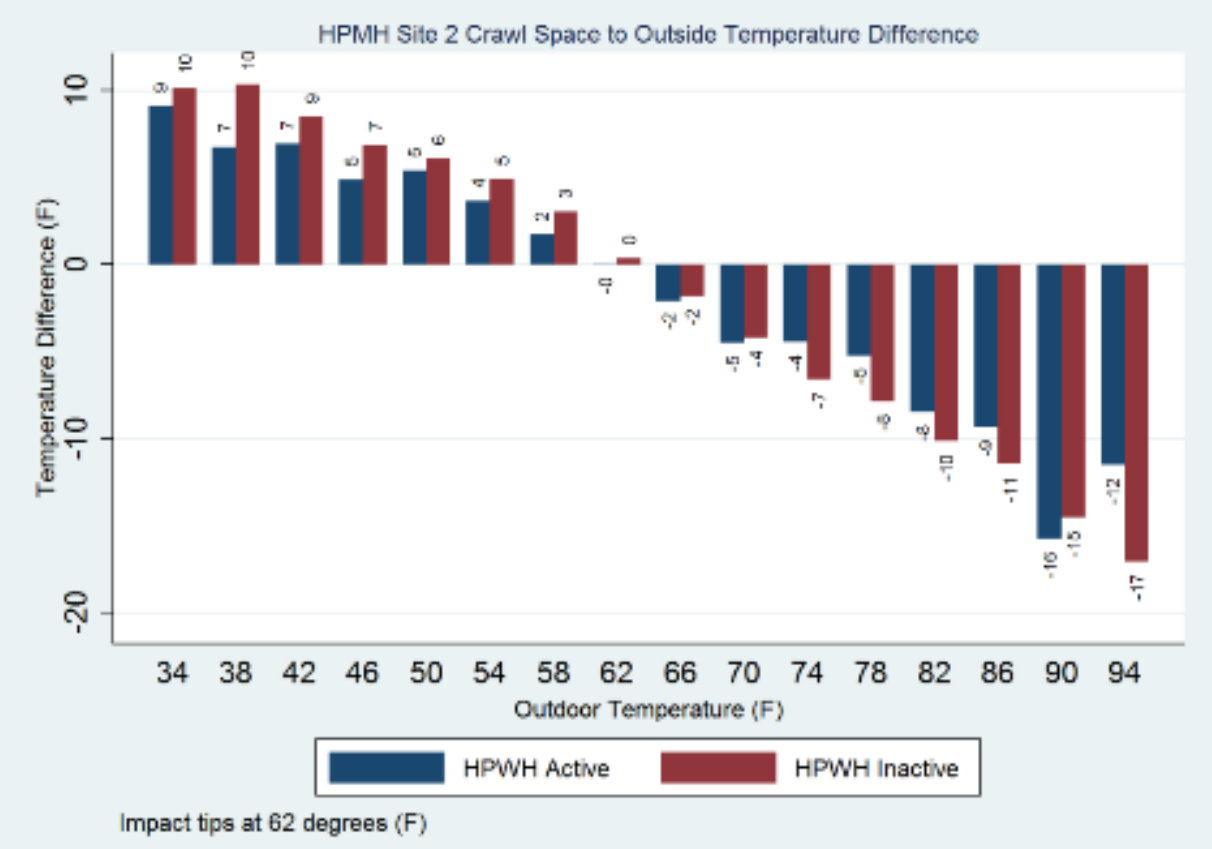

Figure 11. Otis Crawl Space Buffering Effect

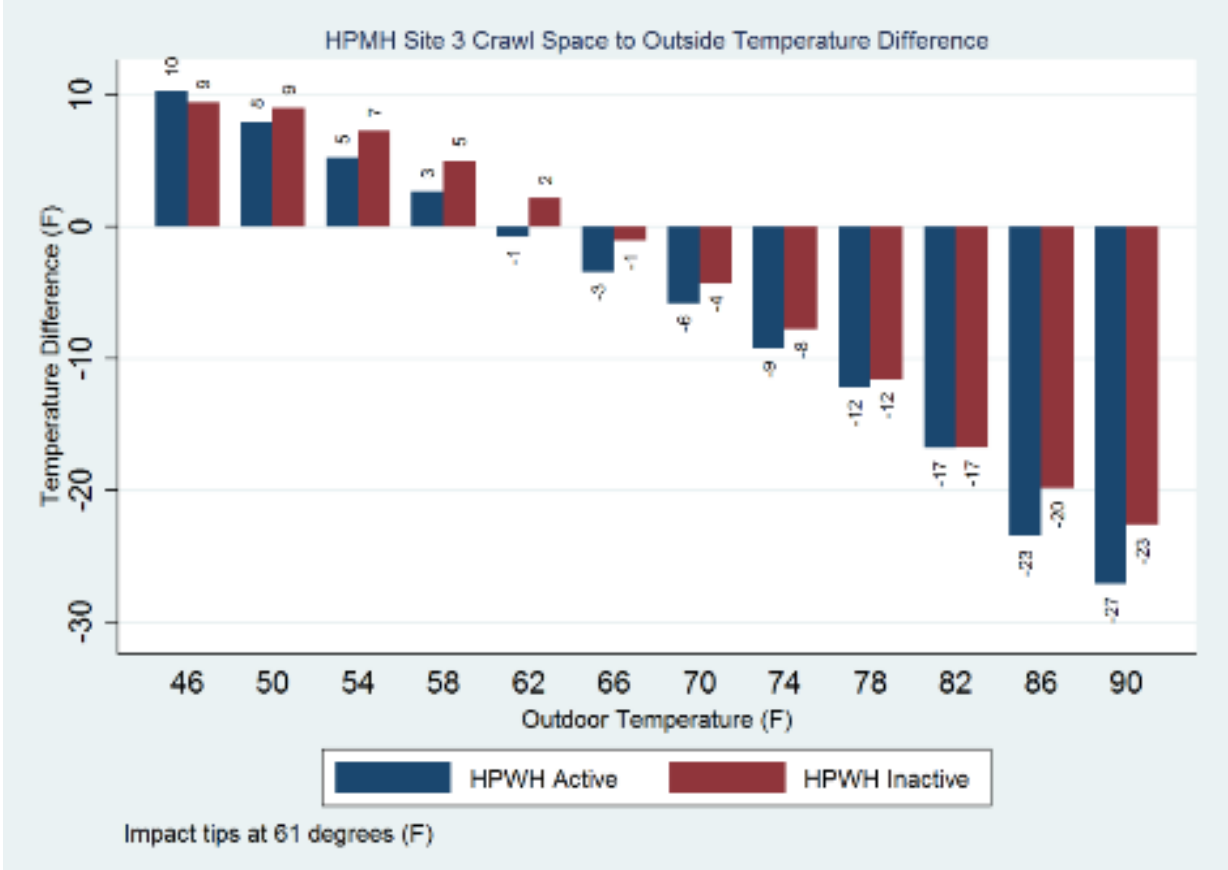


